\title{
Seed germination and early seedling survival of the invasive species Prosopis juliflora (Fabaceae) depend on habitat and seed dispersal mode in the Caatinga dry forest
}

\author{
Clóvis E de Souza Nascimento ${ }^{1,2}$, Carlos Alberto D da Silva ${ }^{3,4}$, Inara R Leal ${ }^{5}$, Wagner de S Tavares ${ }^{6}$, José E Serrão \\ ${ }^{7}$, José C Zanuncio ${ }^{8}$, Marcelo Tabarelli ${ }^{\text {Corresp. } 5}$ \\ ${ }^{1}$ Centro de Pesquisa Agropecuária do Trópico Semi-Árido, Empresa Brasileira de Pesquisa Agropecuária, Petrolina, Pernambuco, Brasil \\ Departamento de Ciências Humanas, Universidade do Estado da Bahia, Juazeiro, Bahia, Brasil \\ 3 Centro Nacional de Pesquisa de Algodão, Empresa Brasileira de Pesquisa Agropecuária, Campina Grande, Paraíba, Brasil \\ 4 Programa de Pós-Graduação em Ciências Agrárias, Universidade Estadual da Paraíba, Campina Grande, Paraíba, Brasil \\ 5 Departamento de Botânica, Universidade Federal de Pernambuco, Recife, Pernambuco, Brasil \\ 6 Asia Pacific Resources International Holdings Ltd. (APRIL), PT. Riau Andalan Pulp and Paper (RAPP), Pangkalan Kerinci, Riau, Indonesia \\ 7 Departamento de Biologia Geral, Universidade Federal de Viçosa, Viçosa, Minas Gerais, Brasil \\ 8 Departamento de Entomologia/BIOAGRO, Universidade Federal de Viçosa, Viçosa, Minas Gerais, Brasil \\ Corresponding Author: Marcelo Tabarelli \\ Email address: mtrelli@ufpe.br
}

Background. Biological invasion is one of the main threats to tropical biodiversity and ecosystem functioning. Prosopis juliflora (Sw) DC. (Fabales: Fabaceae: Caesalpinioideae) was introduced in the Caatinga dry forest of Northeast Brazil at early 1940s and successfully spread across the region. As other invasive species, it may benefit from the soils and seed dispersal by livestock. Here we examine how seed dispersal ecology and soil conditions collectively affect seed germination, early seedling performance and consequently the $P$. juliflora invasive potential.

Methods. Seed germination, early seedling survival, life expectancy and soil attributes were examined in 10 plots located across three habitats (flooding plain, alluvial terrace and plateau) into a humanmodified landscape of the Caatinga dry forest (a total of 12,000 seeds). Seeds were exposed to four seed dispersal methods: deposition on the soil surface, burial in the soil, passed through cattle (Boss taurus) digestive tracts and mixed with cattle manure and passed through mule (Equus africanus asinus $\times$ Equus ferus caballus) digestive tracts and mixed with mule manure. Seeds and seedlings were monitored through a year and their performance examined with expectancy tables.

Results. Soils differed among habitats, particularly its nutrient availability, texture and water with finelytextured and more fertile soils in the flooding plain. Total seed germination was relatively low (14.5\%), with the highest score among seeds buried in the flooding plain (47.4 $\pm 25.3 \%$ ). Seed dispersal by cattle and mule also positively impacted seed germination. Early seedling survival rate of $P$. juliflora was dramatically reduced with few seedlings still alive elapsed a year. Survival rate was highest in the first 30 days and declined between 30 to 60 days with stabilization at 70 days after germination in all seed treatments and habitats. However, survival and life expectancy were higher in the flooding plain at 75 days and lower in the plateau. Prosopis juliflora seedling survival and life expectancy were higher in the case seeds were mixed with cattle manure.

Synthesis. Prosopis juliflora seeds and seedlings are sensitive to water stress and habitat desiccation.

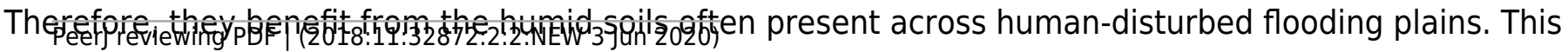


plant also benefits from seed deposition/dispersal by livestock in these landscapes, since cattle manure represents a nutrient-rich and humid substrate for both seeds and seedlings. The quality of the seed dispersal service varies among livestock species, but this key mutualism between exotic species is due to the arillate, hard-coated and palatable seeds. Prosopis juliflora traits allow this species to take multiple benefits from human presence and thus operating as a human commensal. 
1 PeerJ

2

3 Seed germination and early seedling survival of the

4 invasive species Prosopis juliflora (Fabaceae) depend

\section{5 on habitat and seed dispersal mode in the Caatinga}

\section{6 dry forest}

7 Clóvis Eduardo de Souza Nascimento ${ }^{1,2}$, Carlos Alberto Domingues da Silva ${ }^{3,4}$, Inara Roberta

8 Leal $^{5}$, Wagner de Souza Tavares ${ }^{6}$, José Eduardo Serrão ${ }^{7}$, José Cola Zanuncio ${ }^{8}$, Marcelo

9 Tabarelli ${ }^{5}$

${ }^{1}$ Empresa Brasileira de Pesquisa Agropecuária, Centro de Pesquisa Agropecuária do Trópico

12 Semi-Árido, 56300-970, Petrolina, Pernambuco, Brasil

${ }^{2}$ Departamento de Ciências Humanas, Universidade do Estado da Bahia, 48900-000, Juazeiro,

Bahia, Brasil

${ }^{3}$ Empresa Brasileira de Pesquisa Agropecuária, Centro Nacional de Pesquisa de Algodão,

58428-095, Campina Grande, Paraíba, Brasil

${ }^{4}$ Programa de Pós-Graduação em Ciências Agrárias, Universidade Estadual da Paraíba, 58429570, Campina Grande, Paraíba, Brasil

$19{ }^{5}$ Departamento de Botânica, Universidade Federal de Pernambuco, 50670-901, Recife,

Pernambuco, Brasil 
$21{ }^{6}$ Asia Pacific Resources International Holdings Ltd. (APRIL), PT. Riau Andalan Pulp and Paper

22 (RAPP), Pangkalan Kerinci, Riau, Sumatra, Indonesia, 28300

$23{ }^{7}$ Departamento de Biologia Geral, Universidade Federal de Viçosa, 36570-900, Viçosa, Minas

24 Gerais, Brasil

$25{ }^{8}$ Departamento de Entomologia/BIOAGRO, Universidade Federal de Viçosa, 36570-900,

26 Viçosa, Minas Gerais, Brasil

27

28 Corresponding Author:

29 Marcelo Tabarelli

30 Departamento de Botânica, Universidade Federal de Pernambuco, 50670-901, Recife,

31 Pernambuco, Brasil

32 E-mail address: mtrelli@ufpe.br 


\section{Abstract}

Background. Biological invasion is one of the main threats to tropical biodiversity and ecosystem functioning. Prosopis juliflora (Sw) DC. (Fabales: Fabaceae: Caesalpinioideae) was introduced in the Caatinga dry forest of Northeast Brazil at early 1940s and successfully spread across the region. As other invasive species, it may benefit from the soils and seed dispersal by livestock. Here we examine how seed dispersal ecology and soil conditions collectively affect seed germination, early seedling performance and consequently the P. juliflora invasive potential.

Methods. Seed germination, early seedling survival, life expectancy and soil attributes were examined in 10 plots located across three habitats (flooding plain, alluvial terrace and plateau) into a human-modified landscape of the Caatinga dry forest (a total of 12,000 seeds). Seeds were exposed to four seed dispersal methods: deposition on the soil surface, burial in the soil, passed through cattle (Boss taurus) digestive tracts and mixed with cattle manure and passed through mule (Equus africanus asinus $\times$ Equus ferus caballus) digestive tracts and mixed with mule manure. Seeds and seedlings were monitored through a year and their performance examined with expectancy tables.

Results. Soils differed among habitats, particularly its nutrient availability, texture and water with finely-textured and more fertile soils in the flooding plain. Total seed germination was relatively low (14.5\%), with the highest score among seeds buried in the flooding plain (47.4 \pm 25.3\%). Seed dispersal by cattle and mule also positively impacted seed germination. Early seedling survival rate of $P$. juliflora was dramatically reduced with few seedlings still alive elapsed a year. Survival rate was highest in the first 30 days and declined between 30 to 60 days with stabilization at 70 days after germination in all seed treatments and habitats. However, 
58 survival and life expectancy were higher in the flooding plain at 75 days and lower in the 59 plateau. Prosopis juliflora seedling survival and life expectancy were higher in the case seeds

60 were mixed with cattle manure.

61 Synthesis. Prosopis juliflora seeds and seedlings are sensitive to water stress and habitat

62 desiccation. Therefore, they benefit from the humid soils often present across human-disturbed

63 flooding plains. This plant also benefits from seed deposition/dispersal by livestock in these

64 landscapes, since cattle manure represents a nutrient-rich and humid substrate for both seeds and

65 seedlings. The quality of the seed dispersal service varies among livestock species, but this key

66 mutualism between exotic species is due to the arillate, hard-coated and palatable seeds.

67 Prosopis juliflora traits allow this species to take multiple benefits from human presence and

68 thus operating as a human commensal.

69 


\section{Introduction}

72

73

74

75

Biological invasion is an important threat to tropical biodiversity and ecosystem functioning. Increased disturbance by ever-growing human populations will make terrestrial tropical biotas more vulnerable to invasions (Simberloff et al., 2013; Roy et al., 2014; McGeoch et al., 2016). This increased vulnerability is due to alien species benefiting from human disturbances, such as land cleaning and soil degradation by agriculture and livestock. Humans and their commensals, whether intentionally or not, favor alien species by creating altered or novel habitats (Almeida et al., 2015; Jauni et al., 2015; Bellard et al., 2016; Malavasi et al., 2016).

The mechanisms driving successful invasion by alien species and those restricting them to particular habitats or conditions are key topics in invasion science (Blackburn et al., 2014; Catford and Jansson, 2014; Hulme, 2015). The life-history strategy or trait package exhibited by alien species affect their competitive performance or adaptability, while environmental conditions, disturbance regimes, habitat degradation and the structure of native communities (e.g. patterns of species richness and functional composition) are external forces controlling invasion success (Gilioli et al., 2014; Goia et al., 2014; Banerjee and Dewanji, 2017). The intrinsic and external factors collectively define the potential for successful invasion and delimit its ecological context, the geographic coverage and potential damage to native biodiversity. Successful invasions only occur when alien species can overcome external forces (Dalmazzone and Giaccaria, 2014; Li et al., 2014; Svenning et al., 2014). These factors explain why a small fraction of introduced alien species become invasive regardless of ecosystem type or habitat integrity (Kalusová et al., 2013; van Wilgen and Richardson, 2014; Novoa et al., 2015). 
94 across all life-cycle stages (Chapple et al., 2012; Malíková et al., 2012; Mullah et al., 2014), such

95

96

97

98

as vegetative reproduction, massive seed production, effective seed dispersal, high germination success in a wide range of environmental conditions, fast growth and high phenotypic plasticity (Moravcová et al., 2015; van Kleunen et al., 2015; Moran et al., 2017). The effective colonization of human-degraded habitats usually requires dealing with physical stress, particularly reduced soil nutrients and water availability (Boudiaf et al., 2013; Pérez et al., 2015; Rathore et al., 2015). The naturalization and long-term establishment of invasive species depend on integrating adaptive traits as functional strategies (Guo et al., 2018). However, the relative contribution of each trait or strategy vary from case to case (Hulme and Barrett, 2013; Perkins and Nowak, 2013; Rai, 2015).

The Caatinga of Northeast Brazil is one of the largest blocks (nearly 1 million $\mathrm{Km}^{2}$ ) and the world most species-rich seasonally dry tropical forest (Silva et al., 2017). The regional vascular flora reaches 3,000 species with one third endemic, including a myriad of Cactaceae species - making this region the second diversity cactus species center globally (Silva and Souza, 2018; Apgaua et al., 2018; Terra et al., 2018). The Caatinga was inhabited by huntergather people for thousands of years (Leal et al., 2005; Mamede and de Araújo, 2008; Silva et al., 2017). The Europeans arrived in the $16^{\text {th }}$ century and the Caatinga dry forest has been converted into human-modified landscapes by a combination of extensive cattle ranching, smallscale subsistence farming and exploitation of forest products such as firewood, fodder, timber, wood for charcoal, fruits and bushmeat (Silva et al., 2014; Leal et al., 2014; Ribeiro et al., 2015; Silva et al., 2017). Nearly 10 million $\mathrm{m}^{3}$ of firewood and charcoal are obtained per year from native species, while goat (i.e. the exotic Capra aegagrus subspecies hircus L., 1758; 
116 Artiodactyla: Bovidae) herds feeding on native vegetation exceed 16 million heads (Ribeiro et

117 al., 2015; Rito et al., 2017; Sfair et al., 2018). The Caatinga supports around 28 million people,

118 making it one of the most populated semiarid regions and one of the most degraded/vulnerable

119 Seasonally Dry Tropical Forests (SDTFs) globally (Oliveira et al., 2016; Moro et al., 2016; Rito

120 et al., 2016; Schulz et al., 2017; Silva et al., 2017).

121 The alien flora inhabiting the Caatinga includes 205 species of 135 genera and 48

122 families, including 61 Poaceae and 33 Fabaceae invasive species (Almeida et al., 2015). This

123 diverse alien flora includes the evergreen tree Prosopis juliflora (Sw) DC. (Fabales: Fabaceae:

124 Caesalpinioideae), one of the world top 100 undesired species (Nascimento et al., 2014; Almeida

125 et al., 2015). This species is native to the Caribbean, Central America and South America, but

126 has been intentionally introduced worldwide for its economic value, utility to rural populations

127 and ecological rusticity due to its fast growth, ability to fix nitrogen and tolerance to arid

128 conditions and saline soils (Nascimento et al., 2014; Ilukor et al., 2016; Walkie et al., 2016).

129 Prosopis juliflora was introduced in the Caatinga at early 1940s as a food source for

130 livestock and successfully spread across the region by invading and forming monospecific

131 stands, particularly across former agricultural lands along river banks and flooding plains

132 (Nascimento et al., 2014; Almeida et al., 2015; Santos and Diodato, 2015; Oliveira et al., 2017).

133 Prosopis juliflora forms dense stands, apparently excluding or impelling the reestablishment of

134 species-rich assemblages of tree and shrub species, particularly on river banks degraded by

135 shifting cultivation and livestock overgrazing (Pegado et al., 2006; Oliveira et al., 2012;

136 Nascimento et al., 2014). Caatinga dry forests along river banks are structurally complex due the

137 presence of large tree species [e.g., Libidibia ferrea (Mart. ex Tul.) L.P. Queiroz, Piptadenia

138 stipulacea (Benth.) Ducke (Fabales: Fabaceae) and Tabebuia aurea (Silva Manso) Benth. \& 
139 Hook.f. ex S. Moore (Lamiales: Bignoniaceae)] and support a diverse flora, including endemic

140 species such as the cactus Cereus jamacaru DC. and Pilosocereus gounellei (F.A.C. Weber ex

141 K. Schum.) Luetzelb. (Caryophyllales: Cactaceae). Prosopis juliflora, as other invasive species,

142 may benefit from the soils and seed dispersal by livestock (Kebede and Coppock, 2015; Pasha et

143 al., 2015; Alvarez et al., 2017) but the ultimate forces permitting successful invasion of Caatinga

144 dry forest by this plant needs further studies (Shackleton et al., 2015; Abdulahi et al., 2017;

145 Naudiyal et al., 2017).

146 In this study we investigate seed germination, early seedling survival and life expectancy

147 in P. juliflora, as well as soil attributes across the three main habitats covered by Caatinga dry

148 forest to understand how seed dispersal ecology and soil conditions collectively affect seedling

149 performance and consequently the invasive potential of $P$. juliflora. Seeds exposed to four seed

150 dispersal treatments were deposited across flooding plain, alluvial terrace and plateau habitats,

151 with seed and seedling fate being monitored for a year. The potential mechanisms behind

152 differential seedling performance, especially a positive synergism between human disturbance,

153 key ecological services provided by livestock and the life-history traits exhibited by P. juliflora

154 was studied.

155

156 Material \& Methods

157 Study site. The study was carried out in 10 sites across a $3.5-\mathrm{km}^{2}$ human-modified Caatinga

158 landscape $\left(9^{\circ} 00^{\prime} \mathrm{S}, 40^{\circ} 13^{\prime} \mathrm{W} ; 377 \mathrm{~m}\right.$ altitude) covering three habitats: flooding plain, alluvial

159 terrace, and plateau (Fig. S1 and Fig. S2). This landscape is typical of the Caatinga, with farming

160 households devoted to livestock production with animals raised extensively and feeding on the

161 Caatinga vegetation plus small patches devoted to subsistence agriculture and remnant patches of 
162 Caatinga dry forest; i.e. the traditional Caatinga land use (Sampaio and Costa, 2011). The 163 landscape stretches over sedimentary basins, mountains, plateaus and ravines covered by

164 cambisols, eutrophic podzols, lithosols, non-calcic brown soils and planosols along the São

165 Francisco River valley (Razanamandranto et al., 2004). The river terrace has alluvial deposits

166 from the valley slopes with sedimentary clay, sandy or silty material in stratified silt layers

167 (Miranda et al., 2014). The flooding plain, with slopes between 0 and $2^{\circ}$ (Miranda et al., 2011), 168 consists of recent sediments from terraces (Babawi et al., 2016). The alluvial terrace, also called

169 the slope, consists of flat areas or benches, usually situated above the river level, with gravel or 170 thick sediment forming ancient terraces (Mukherjee et al., 2017). The plateau is a flat terrain 171 covered by a sedimentary clay mantle, which spreads following the river terraces (Silva et al.,

172 2008; Ferraz et al., 2003). The regional climate is hot semi-arid, with mean annual temperature 173 of $26.3{ }^{\circ} \mathrm{C}$ and relative humidity of $61.7 \%$. The $570 \mathrm{~mm}$ annual rainfall is concentrated between

174 January and April (Ramos et al., 2011). The focal landscape was completely covered by

175 Caatinga dry forest prior to European settlement (Silva et al., 2008). Regionally, Cactaceae,

176 Euphorbiaceae and Fabaceae are the most species-rich plant families (Leal et al., 2005; Silva et 177 al., 2008).

179 Soil attributes. Soil attributes were estimated based on 10 soil samples per habitat type 180 (flooding plain, alluvial terrace and plateau). Soil moisture was determined twice a week at 20 181 cm depth from March 2014 to February 2015 (Francesca et al., 2010). The soil samples were 182 weighed to determine the wet mass (mw, g), dried in an oven at $105{ }^{\circ} \mathrm{C}$ for 24 hours and weighed 183 again to determine their dry mass $(\mathrm{md}, \mathrm{g})$. Soil moisture was determined by $H\left(g, g^{-1}\right)$ $184=(m d-m h) \div m d$ or $H(\%)=(m d-m h) \div m d \times 100$. Physical (field capacity, sand, silt 
185 and clay content) and chemical soil attributes [soil organic matter, phosphorus, potassium,

186 calcium, magnesium, sodium, aluminum and cation exchange capacity (CEC)] were also

187 obtained via 10 soil samples per habitat type, with samples at 0-20 cm depth (Lopes et al., 2013).

188 Soil analyses were performed in the Laboratory for Soil, Water and Plant Tissue Analysis at

189 EMBRAPA Semi-Arid according to standard international protocols (Marques et al., 2007;

190 Galindo et al., 2008).

191

192 Seed germination and seedling performance across habitats. Prosopis juliflora seeds were

193

194

195

196

197

198

199

200

201

202

203

204

205

206

207 exposed to four seed dispersal treatments as follows: seeds with artificially broken dormancy

deposited on the soil surface (T1); seeds with artificially broken dormancy buried in the soil to a depth of $1.0 \mathrm{~cm}(\mathrm{~T} 2)$; seeds that passed through the digestive tract of cattle (Bos taurus

subspecies indicus L., 1758; Artiodactyla: Bovidae) and mixed with cattle manure (hereafter

cattle-dispersed seeds) (T3) and seeds that passed through the digestive tract of mules (donkey,

Equus africanus subspecies asinus L., $1758 \times$ mare, Equus ferus subspecies caballus L., 1758;

Perissodactyla: Equidae) and mixed with mule manure (hereafter mule-dispersed seeds) (T4).

These four seed dispersal treatments resemble natural seed dispersal modes and fates in the

Caatinga, as ripe fruits can be (1) consumed by livestock and deposited on the soil surface

immersed in manure; (2) remain intact on the ground and as the pod rots, seeds are deposited on

the soil surface and (3) carried by runoff and deposited in soil sediments (dos Santos et al.,

2016). These fates need further studies, although ripe pods are consumed by livestock including

cattle, goats, horses and mules (Nascimento et al., 2014). Seeds were manually collected from

mature fruits from several trees collected on the ground throughout 2013. Seeds were used to

feed livestock first and their manure collected.

Peer) reviewing PDF | (2018:11:32872:2:2:NEW 3 Jun 2020) 

habitats (40 plots per habitat, Fig. S1). One thousand seeds were sown per treatment and habitat, totaling 12,000 seeds (four treatments $\times$ three habitats $\times 1,000$ seeds per treatment). Seed dispersal treatments were set up in mid-March (i.e. rainy season) of 2014. Seeds were collected from several trees and animal dungs in the year preceding sowing experiments. Seed dormancy was broken artificially by making a small incision with blunt scissors on the opposite side of the micropylar region, while those that had passed through the animal digestive tract were extracted from dried dung (Nascimento et al., 2014). Seeds obtained from trees were sown at $10 \times 10 \mathrm{~cm}$ spacing and those collected from the manure were separated, counted, mixed with $500 \mathrm{~mL}$ of the respective animal dung and sown at $10 \times 10 \mathrm{~cm}$ spacing. Seed germination and seedling survival were evaluated for each of the three habitats every five days during the first 30 days and every 15 days thereafter for one year. Prosopis juliflora germination is epigeal (Dube et al., 2010) and sprouted seeds (with cotyledons) were marked with toothpicks and protected with wire netting to prevent animal damage. Seeds with their first cotyledon open were classified as seedlings.

Life expectancy and survival tables. Life expectancy and survival tables of $P$. juliflora were calculated (Bogino and Jobbágy, 2011) for each dispersal treatment and habitat considering age classes of 15 days $(x=15)$. The number of $P$. juliflora survivors at the beginning of each age class $(L x)$ and at the germination and seedling life stages were estimated based on survival $(l x)$ in these stages (Caswell, 1996) as follow: (a) number of dead individuals during the age class $x$ $(d x): d x=L_{x}-L_{x+1}$; (b) mortality ratio for the age class $x(q x): q x=d_{x} \div L_{x}$; (c) survival rate

229 during age $x(s x): s x=1-q_{x} ;(\mathrm{d})$ age structure $(E x)$ as the number of alive plants from each age 230 class: $E x=\left(L_{x}+L_{x+2}\right) \div 2$; (e) cumulative number of living individuals $(T x)$ by: $T x=$ 
$231 \sum_{j \geq x}^{y} E x$ where $\mathrm{j}$ represents any age greater than or equal to that of class $x$; and (f) life

232 expectancy for individuals of age class $x(e x)$ : ex $=T_{x} \div L_{x}$.

233

234 Data analysis. Differences in soil attributes were examined via analysis of variance and Tukey's

235 HSD (honestly significant difference) test $(p<0.05)$ (Tukey, 1949). Non-normal (non-

236 parametric) data obtained from the three habitats were compared using the Kruskal-Wallis test

$237(p<0.05)$ (Wallis, 1952). Differences on average seed germination (\%) across habitats and seed

238 dispersal modes were examined via a two-way ANOVA followed by Tukey’s HSD test. Number

239 of germinated seeds was square-rooted transformed prior analysis to approach data normality. As

240 habitat and soil moisture were autocorrelated, soil moisture was not adopted as an explanatory

241 variable for seed germination and seedling survival/life expectancy. All tests were run in

242 BioEstat 5.0 program (Ayres et al., 2007).

243

244 Results

245 Soil physical attributes. Caatinga habitats differed in terms of soil physical attributes. Field

246 capacity was higher in the flooding plain $(\mathrm{F}=8.5454, d f=2, p=0.0016$; Fig. $1 \mathrm{~A})$, with this

247 habitat and the terrace supporting higher soil moisture $(\mathrm{H}=12.5507, d f=2, p=0.0019)$ than the

248 plateau (Fig. 1B). Soil clay content was higher in the flooding plain followed by the plateau and

249 the alluvial terrace $(\mathrm{H}=9.0142, d f=2, p=0.011)$. The silt score was also highest in the flooding

250 plain as compared to plateau $(\mathrm{F}=6.6178, d f=2, p=0.0048)$. However, soil did not differ in

251 terms of sand content $(\mathrm{F}=8.2452, d f=2, p=0.0019$; Fig. 2A $)$.

252 
253 Soil chemical attributes. Overall soils varied little within each habitat, but they greatly differed

254 in terms of chemical attributes associated with soil fertility across the habitats. We shall mention

255 a higher content of phosphorus $(\mathrm{H}=16.935, d f=2, p=0.0002)$, potassium $(\mathrm{H}=16.87, d f=2, p=$

256 0.0002), and $\mathrm{CEC}(\mathrm{H}=12.18, d f=2, p=0.0023)$ in the flooding plain as compared to plateau

257 (Fig. 2B), while Al content was higher in the plateau $(\mathrm{H}=21.618, d f=2, p=0.0001)$. Overall,

258 terrace soils exhibited intermediated scores, with the exception of organic matters as these soils

259 presented reduced contents $(\mathrm{H}=17.8655, d f=2, p=0.0001)$.

261 Seed germination. From a total 12,000 seeds, only $14.5 \%(1,746$ seeds) germinated and seed germination varied according to both habitat and seed dispersal mode (Tables 1 and 2); i.e. a significant interaction between habitat and seed dispersal mode. Considering habitats, higher average germination occurred among those seeds buried in the flooding plain $(47.4 \pm 25.3 \%$; mean $\pm \mathrm{SD})$, and terrace $(33.4 \pm 25.8 \%)$, while seeds in the plateau experienced the lowest rates, from 0.7 to $12.9 \%$. Among seed dispersal modes, seeds in the soil surface exhibited the lowest scores $(0.7-5.3 \%)$, in contrast to the positive impacts caused by seed burial or dispersal via by cattle and mule. Overall, seed dispersal mode was more impacting than habitat for seed germination.

271 Seedling survival and life expectancy. In the flooding plain and terrace (Figs. 3A-3D and 4A272 4C), P. juliflora seedling survival declined steeply in the first 30 days after germination, 273 particularly among seedlings from buried seeds. After this period, survival declined moderately

274 from 30 to 60 days and tended to stabilize 70 days after germination for all seed dispersal treatments. In the plateau, seedling survival tended to stabilize 15 days after germination (soil 
276 surface and buried seeds), but only at 30 days in the case of seedlings from cattle/mule dispersed

277 seeds (Figs. 5A-5D). Elapsed 180 days after seed germination started, almost all seedlings were

278 already dead in terrace and plateau as seedlings died faster in these habitats, particularly

279 seedlings that emerged from seeds left in the soil surface. In fact, only one seedling from surface

280 seeds $(3,000$ seeds $)$ achieved one year; i.e. a seedling in the flooding plain.

281 Moving to life expectancy, two peaks were observed across seed dispersal modes in the

282 flooding plain. A first peak occurred approximately 75 days after germination, with the

283 exception of seedlings from buried seeds. For these seedlings the first peak occurred at 180 days.

284 The second peak in life expectancy was observed at 195, 210, 240 and 255 days among seedlings

285 from seeds dispersed by cattle, on the soil surface, buried and dispersed by mules, respectively.

286 Life expectancy of $P$. juliflora reached 345 days across all treatments (Figs. 3A-3D; Table S1).

287 In the terrace, a peak of life expectancy occurred within the first 60 days after germination,

288 without further increments from this period onwards. Exception was among seedlings from seeds

289 deposited on the soil surface, whose first peak of life expectancy occurred at 90 day (Figs. 4A-

290 4C; Table S2). The life expectancy in the terrace reached 150 days for all seed treatments, except

291 for those buried in the soil surface, which reached 165 days.

292 In the plateau, life expectancy among seedlings from soil surface and buried seeds were

293 higher in the first 15 days after germination and tended to decrease consistently from

294 germination to 45 and 120 days of age, respectively. On the other hand, there were peaks in life

295 expectancy at 30 and 60 days among seedlings dispersed via cattle and mules, respectively.

296 However, life expectancy reached 120 and 165 days among seeds buried and cattle-dispersed,

297 respectively (Figs. 5A-5D; Table S3). 
Discussion

300

The main habitats covered by the Caatinga dry forest differ in soil attributes or

301

302

303

304

305

306

307

308

309

310

311

312

313

314

315

316

317

318

319

320

321 conditions. Overall soils along flooding plains and terraces have finer texture and are more humid and fertile than those on the plateau, which are sandy and xeric. In these habitats, both seed germination and seedling survival of $P$. juliflora are relatively reduced. However, the way seeds are dispersed and deposited (i.e. seed dispersal treatments) appears to respond to soil conditions and greatly influences seed germination and early seedling performance across the main Caatinga habitats, although in most of the situations seed germination can be considered low $(\leq 20 \%)$ and highly variable. The chances of seedling survival when coated in manure and across flooding plains are higher, while those deposited on the soil surface on the plateau have a lower survival probability. Thereby seedling life span is longer from those originated with seeds immersed into cattle manure. Moreover, the benefit for seedling dispersal depends on animal species (cattle vs. mule) and the habitat but seedling survival can be extremely low. In synthesis, early seed-seedling fate of $P$. juliflora in the Caatinga dry forest depends on the seed dispersal mode and the habitat seeds are delivered. In other words, interactions between soil attributes and seed dispersal by exotic species apparently define the $P$. juliflora potential as an invasive species across human-modified Caatinga landscapes.

Such a role played by physical conditions has been documented elsewhere. The dominant species Stipa breviflora Griseb. (Poales: Poaceae) expansion potential depends on climate changes in Chinese temperate grasslands (Lv and Zhou, 2018). Extreme climatic change in Mediterranean rivers is suggested to promote the disappearance of the pioneer and young succession stages of riparian woodlands (Rivaes et al., 2013), particularly evident in Europe (Rivaes et al., 2014). Moreover, soil differs across habitats, through which $P$. juliflora has been 
322 documented to exhibit extreme variations in establishment and stand density in the Caatinga dry

323 forest (Bailis and McCarthy, 2011). Prosopis juliflora stands have been reported with densities

324 as high as 140.39 stems per ha across flooding plains and alluvial deposits at the Keoladeo

325 National Park in Rajasthan, India (Mukherjee et al., 2017) and in Tamil Nadu, India (Gandhi and

326 Pandian, 2014). Such dense monospecific stands suggest soil conditions and seedling ecology as

327 potential key drivers for this invasive species as previously documented for other regions in

328 which Prosopsis species are invasive (Ansley et al., 2018). Prosopis species largely benefit from

329 seed dispersal by domestic animals via dung pellets, improving seed germination and seedling

330 performance and leading to higher life expectancy (Miranda et al., 2011, 214; Razanamandranto

331 et al., 2004). Seeds deposited on the soil surface without manure had the worse seedling

332 performance and survival in our focal landscape; similar to that documented across a variety of

333 habitats and biotas (Babawi et al., 2016; Mukherjee et al., 2017).

$334 \quad$ Prosopis juliflora as an invasive plant species benefiting from dispersal services offered

335 by exotic animals is far from novel, with a number of examples for species of this genus (Abbas

336 et al., 2018). Ingestion and deposition by livestock is not required for Prosopis seeds to

337 germinate, but it improves seed germination, seedling performance and long-distance seed

338 dispersal of this plant as it has a patchy distribution and no native vertebrate species have been

339 found to disperse $P$. juliflora seeds in the Caatinga region. Seed dispersal by native ungulates

340 [(i.e. dears, Mazama americana Erxleben, 1777 and Mazama gouazoubira Fischer, 1814

341 (Artiodactyla: Cervidae)] is theoretically possible but large vertebrates have been intensively

342 extirpated in the Caatinga region (Bragagnolo et al., 2019; de Oliveira et al., 2019). Caatinga

343 supports nearly 30 million cattle, goats and mules (Sampaio and Costa, 2011; Santos et al., 2017)

344 as a large number of active seed dispersers which spread through diverse habitat types, from old- 
345 growth forest stands to degraded areas (Sampaio and Costa, 2011). Livestock frequently access

346 humid habitats such as river banks on their daily search for fresh water and native forage (Dias et

347 al., 2019; Lopes et al., 2019). Moreover, fodder availability is seasonal and scarce (Costa et al.,

348 2016), while P. juliflora fruits and foliage represent a permanent and appreciable food source for

349 livestock, likely stimulating its fruit consumption.

350 Prosopis has relatively hard pods and its sweet-arillate seeds probably evolved as a

351 response to consumption by native ungulates [e.g. cattle, goats, horses, mules and sheep Ovis

352 aries L., 1758 (Artiodactyla: Bovidae)], as an adaptation for contemporary consumption and

353 seed dispersal by domestic livestock (Nascimento et al., 2014; Almeida et al., 2015). Although a

354 substantial seed portion may be damaged or digested when consumed by livestock, the benefits

355 from dispersal outweigh this drawback. This may be particularly true in the Caatinga as the

356 native flora (mostly abiotically-dispersed) does not benefit from the dispersal services offered by

357 livestock.

358 Higher nutrient and water content in both flooding plain soils and livestock manure may

359 enhance seedling performance of Prosopis species. This was suggested for Prosopis africana

360 (Guill. \& Perr.) Taub. seeds in sheep and zebu manure in the Sudanian savanna

361 (Razanamandranto et al., 2004) and P. juliflora in animal manure in the Caatinga in northeast

362 Brazil (Miranda et al., 2011, 2014). Causal mechanisms responsible for differential seedling

363 performance of that plant across seed dispersal modes and habitats were not explicitly examined

364 in our focal landscape. Seeds deposited on the soil surface rarely germinate due to dehydration as

365 observed for Prosopis ferox Griseback and Prosopis flexuosa DC. across semiarid regions of

366 Argentina and Sudan (Campos et al., 2011; Morandini et al., 2013; Yoda et al., 2015). High

367 Prosopis caldenia Burkart seed mortality has also been related to soil water availability 
368 reduction across semiarid rangelands of Central Argentina (de Villalobos et al., 2005; de

369 Villalobos and Peláez, 2015; Risio et al., 2016).

Fine-textured soils with greater silt and clay quantities, as observed in the flooding plain,

371 are expected to increase water retention and storage capacity, and thus may increase both seed

372 germination and plant survival. A similar phenomenon was observed for $P$. caldenia and $P$.

373 glandulosa since allometric growth and survival was directly proportional to the water

374 availability along a topographic gradient in the Chihuahuan Desert, Mexico, in the semiarid

375 rangelands of Central Argentina and in the arid and semiarid ecosystems of the United States of

376 America (USA), respectively (Martínez and López-Portillo, 2003; de Villalobos et al., 2005;

377 Maestre and Reynolds, 2006). Water storage capacity (Arcone et al., 2008) and organic matter,

378 phosphorus and calcium accumulation are usually higher in fine-textured soils with greater silt

379 and clay quantities, found mainly in gallery forests (Jiménez et al., 2008), which gives these soils

380 a greater CEC (Shiferaw et al., 2004; Silva et al., 2008). In synthesis, P. juliflora seeds and

381 seedlings are sensitive to water stress and habitat desiccation.

The higher nutrient availability in the flooding plain and terrace, along with the low

aluminum content in the flooding plain, may also be important because excess of this element in

the soil can impair the calcium, magnesium, phosphorous and potassium absorption by Prosopis plants, as reported for P. juliflora in the Caatinga (Jiménez et al., 2008; Oliveira et al., 2017).

However, calcium and magnesium counteract this detrimental effect as observed for Prosopis

alba Griseb., Prosopis pubescens Benth. and Prosopis ruscifolia G. in the central and western

Gran Chaco phytogeographical region, Argentina, and in El Paso, Texas, USA, respectively

(Velarde et al., 2005; Meloni et al., 2012; Zapala et al., 2014). The soil nutrient availability 
391 similar to that reported for Prosopis cineraria (L.) Druce (Ghaff) in United Arab Emirates (Gil

392 and Al-Shankiti, 2015; Song et al., 2017). Nutrient-rich soils increase the P. juliflora seedling

393 establishment, allowing its embryos to grow quickly (Nasr et al., 2012; Patil and Karadge, 2012;

394 El-Keblawy and Abdelfatah, 2014).

395 The high nutrient and water availability in animal manure also apparently create suitable

396 microhabitats for seeds and seedlings. This substrate is favorable during the critical germination

397 and emergence periods, especially considering the spatially erratic rainfall in the Caatinga even

398 in the rainy season (Sampaio and Costa, 2011). Such services provided by livestock manure

399 benefit the Prosopis seeds of different species from South America to the Middle East and Africa

400 (Majd et al., 2013; Westphal et al., 2015; Araujo et al., 2017). On the other hand, the rapid

401 dehydration and hardening of animal manure reduced seed germination of $P$. glandulosa in the

402 arid and semiarid regions of northeastern Mexico and in the drylands of Japan (Garza et al.,

403 2013; Abdalla et al., 2017). The lower soil moisture in the plateau of the Caatinga accelerated the

404 drying and hardening process of cattle and mule manure (CE de SN, personal observation). This

405 adversely affected the $P$. juliflora germination and emergence and contributed to its lower

406 survival and life expectancy compared to the flooding plain and terrace habitats.

407

The higher survival rate and life expectancy of $P$. juliflora seedlings germinated from

408 seeds mixed with cattle manure compared to those mixed with mule manure in the plateau can be

409 attributed to differences in the composition of these animal dungs (Campos et al., 2008;

410 Nascimento et al., 2014). Mule manure has a lower water content and higher fibrous sheath

411 content encasing seeds (Gonçalves et al., 2013). The fibrous sheath covering the seeds probably

412 reduces seed imbibition due to the fact that these animals are not ruminants like cattle

413 (Gonçalves et al., 2013). Both exotic and native ungulates can favor invasive plant species by (1) 
414 creating disturbed habitats via feeding, trampling and movement, (2) controlling or eliminating

415 palatable native species and (3) dispersing seeds via endozoochory and epizoochory (Vavra et

416 al., 2007). The colonization and direct seed dispersal services provided by domestic ungulate

417 livestock was confirmed, and evidences for improved germination and seedling performance

418 associated with fruit consumption and the seed dispersal, coated in protective manure, to suitable

419 habitats was also confirmed. However, even in this favorable context few seedlings appear to

420 survive longer and move to other life stages, suggesting that $P$. juliflora invasion capacity in the

421 Caatinga dry forest relies on intense seed production and dispersal on suitable habitats.

422 Caatinga dry forest has been converted to small-scale farming for the agriculture and

423 livestock subsistence, as found in other dry forests and savannas globally (Miccolis et al., 2017;

424 Pérez-Marin et al., 2017). Farming has a continuous demand for the intentional introduction of

425 useful alien species such as cattle, goats and the multiple-use shrub P. juliflora, which has now

426 established throughout the Caatinga (Nascimento et al., 2014; Almeida et al., 2015; Ilukor et al.,

427 2016; Walkie et al., 2016). Seed and seedling sensitivity to water stress and desiccation limits the

428 P. juliflora proliferation and restricts its establishment to humid/more fertile soils even when its

429 seeds are coated in livestock manure. Prosopis juliflora has spread throughout the Caatinga

430 region establishing monospecific stands across flooding plains, river banks and sedimentary

431 deposits despite such a life-history limitation. This invasion relies on a close mutualism between

432 human populations and their commensals as agriculture provided degraded habitats, affect soil

433 conditions across river banks via deposition of fine material, while livestock provides seed

434 dispersal services due to the presence of arillated and hard-coated seeds; i.e. a high-quality seed

435 dispersal service that is not available for the native flora in the Caatinga, thereby conferring an

436 adaptive advantage to Prosopis species. Prosopis juliflora is expected to spread in the Caatinga 
437 with dense populations locally because the rural populations continue to convert Caatinga dry

438 forest into degraded habitats (Sfair et al., 2018). The mutualism with human populations favors

439 P. juliflora, as found for other invasive Prosopis species across semiarid rangelands globally

440 (Busso et al., 2013). A general perspective on how some P. juliflora life-history traits confer

441 invasive capacity has been described (at least relative to early establishment), but other traits

442 (e.g. resprouting capacity, seedling tolerance to herbivory and trampling, allelopathic abilities)

443 enabling $P$. juliflora to become a human commensal deserves further investigation.

\section{Conclusions}

446 The Prosopis juliflora invasion capacity promoted by patterns of seed germination and seedling

447 survival depends on habitat and seed dispersal mode in the Caatinga dry forest as this species

448 benefits from human-disturbed, humid soils and manure-involved seeds provided by livestock.

449 This perspective highlights plant-animal interactions among exotic species as potential driver for 450 successful invasion, proliferation and habitat distribution of invasive plants in human-modified

451 landscapes or rangelands.

452

\section{Acknowledgments}

454 To Asia Science Editing (http://www.asiascienceediting.com/) of Republic of Ireland and Kieran

455 Withey (Lancaster University in Lancaster, United Kington) for English editing and correction of 456 an early and final version of this manuscript, respectively. Three anonymous Referees offered 457 constructive criticism. 
460

461

462

463

464

465

466

467

468

469

470

471

472

473

474

475

476

477

478

479

480

481

\section{References}

Abbas AM, Mancilla-Leytón JM, Castillo JM. 2018. Can camels disperse seeds of the invasive tree Prosopis juliflora? Weed Research 58,221-228. DOI 10.1111/wre.12298

Abdalla MA, Elkarim AHA, Taniguchi T, Endo T, Yamanaka N. 2017. Phytoremediation of calcareous saline-sodic soils with mesquite (Prosopis glandulosa). Acta Agriculturae Scandinavica, Section B - Soil \& Plant Science 67,352-361. DOI $10.1080 / 09064710.2017 .1281432$

Abdulahi MM, Ute JA, Regasa T. 2017. Prosopis juliflora L: Distribution, impacts and available control methods in Ethiopia. Tropical and Subtropical Agroecosystems 20,75-89.

Almeida WR, Lopes AV, Tabarelli M, Leal IR. 2015. The alien flora of Brazilian Caatinga:

Deliberate introductions expand the contingent of potential invaders. Biological Invasions 17,51-56. DOI 10.1007/s10530-014-0738-6

Alvarez M, Leparmarai P, Heller G, Becker M. 2017. Recovery and germination of Prosopis juliflora (Sw.) DC seeds after ingestion by goats and cattle. Arid Land Research and Management 31,71-80. DOI 10.1080/15324982.2016.1234521

Ansley RJ, Zhang T, Cooper C. 2018. Soil moisture, grass production and mesquite resprout architecture following mesquite above-ground mortality. Water 10,1243. DOI $10.3390 / \mathrm{w} 10091243$

Apgaua DMG, Pereira DGS, Santos RM, Menino GCO, Pires GG, Fontes MAL, Tng DYP. 2018. Floristic variation within seasonally dry tropical forests of the Caatinga Biogeographic Domain, Brazil, and its conservation implications. International Forestry Review 17,33-44. DOI 10.1505/146554815815834840 
482 Araujo MER, Pérez DR, Bonvissuto GL. 2017. Seed germination of five Prosopis shrub species

483

484

485

486

487

488

489

490

491

492

493

494

495

496

497

498

499

500

501

502

503

504

(Fabaceae-Mimosoideae) from the Monte and Patagonia phytogeographic provinces of Argentina. Journal of Arid Environments 147,159-162. DOI

10.1016/j.jaridenv.2017.07.019

Arcone S, Grant S, Boitnott G, Bostick B. 2008. Complex permittivity and clay mineralogy of grain-size fractions in a wet slit soil. Geophysics 73,J1-J13. DOI 10.1190/1.2890776

Ayres M, Ayres Júnior M, Ayres DL, Santos AS. 2007. BioEstat: Aplicações estatísticas nas áreas das ciências biológicas e médicas. Versão 5.0. Belém, Pará: Sociedade Civil Mamirauá, MCT-CNPq. 364 p.

Babawi FF, Campbell SD, Mayer RJ. 2016. Seed fall, seed predation, twigging and litter fall of Cascabela thevetia (L.) Lippold. Rangeland Journal 38,569-577. DOI

\subsection{1/RJ16021}

Bailis R, McCarthy H. 2011. Carbon impacts of direct land use change in semiarid woodlands converted to biofuel plantations in India and Brazil. Global Change Biology Bioenergy 3,449-460. DOI 10.1111/j.1757-1707.2011.01100.x

Banerjee AK, Dewanji A. 2017. Native exotic relationships in plant communities: The role of exotic dominance in framing community composition. Ecological Research 32,653665. DOI $10.1007 / \mathrm{s} 1128$

Bellard C, Cassey P, Blackburn TM. 2016. Alien species as a driver of recent extinctions. Biological Letters 12,20150623. DOI 10.1111/oik.01416

Blackburn TM, Essl F, Evans T, Hulme PE, Jeschke JM, Kühn I, Kumschick S, Marková Z, Mrugała A, Nentwig W, Pergl J, Pyšek P, Rabitsch W, Ricciardi A, Richardson DM, Sendek A, Vilà M, Wilson JRU, Winter M, Genovesi P, Bacher S. 2014. A unified 
classification of alien species based on the magnitude of their environmental impacts. PLoS Biology 12,e1001850. DOI 10.1371/journal.pbio.1001850

507

508

509

510

511

512

513

514

515

516

517

518

519

520

521

522

523

524

525

526

527

Bragagnolo C, Gama GM, Vieira FAS, Campos-Silva JV, Bernard E, Malhado ACM, Correia RA, Jepson P, de Carvalho SHC, Efe MA, Ladle RJ. 2019. Hunting in Brazil: What are the options? Perspectives in Ecology and Conservation 17,71-79. DOI 10.1016/j.pecon.2019.03.001

Bogino SM, Jobbágy EG. 2011. Climate and groundwater effects on the establishment, growth and death of Prosopis caldenia trees in the Pampas (Argentina). Forest Ecology and Management 262,1766-1774. DOI 10.1016/j.foreco.2011.07.032

Boudiaf I, Baudoin E, Sanguin H, Beddiar A, Thioulouse J, Galiana A, Prin Y, Le Roux C, Lebrun M, Duponnois R. 2013. The exotic legume tree species, Acacia mearnsii, alters microbial soil functionalities and the early development of a native tree species, Quercus suber, in North Africa. Soil Biology and Biochemistry 65,172-179. DOI 10.1016/j.soilbio.2013.05.003

Busso CA, Bentivegna DJ, Fernández OA. 2013. A review on invasive plants in rangelands of Argentina. Interciência 38,95-103.

Campos CM, Campos VE, Mongeaud A, Borghi CE, de los Ríos C, Giannoni SM. 2011. Relationships between Prosopis flexuosa (Fabaceae) and cattle in the Monte Desert: Seeds, seedlings and saplings on cattle-use site classes. Revista Chilena de Historia Natural 84:289-299. DOI 10.4067/S0716-078X2011000200013

Campos CM, Peco B, Campos VE, Malo JE, Giannoni SM, Suárez F. 2008. Endozoochory by native and exotic herbivores in dry areas: Consequences for germination and survival of Prosopis seeds. Seed Science Research 18,91-100. DOI 10.1017/S0960258508940344 
528 Caswell H. 1996. Analysis of life table response experiments. 2. Alternative parameterizations 529 for size- and stage-structured models. Ecological Modelling 88,73-82. DOI

530 10.1016/0304-3800(95)00070-4

531 Catford JA, Jansson R. 2014. Drowned, buried and carried away: Effects of plant traits on the 532 distribution of native and alien species in riparian ecosystems. New Phytologist 205,1936. DOI 10.1111/nph.12951

534 Chapple DG, Simmonds SM, Wong BBM. 2012. Can behavioral and personality traits influence the success of unintentional species introductions? Trends in Ecology and Evolution 27,57-64. DOI 10.1016/j.tree.2011.09.010

537

538

539

540

541

542

543

544

545

546

547

548

549

Costa CAG, Araújo JC, Lopes JWB, Pinheiro EAR. 2016. Permanence of water effectiveness in the root zone of the Caatinga biome. Revista Caatinga 29,692-699. DOI 10.1590/198321252016v29n320rc

Dalmazzone S, Giaccaria S. 2014. Economic drivers of biological invasions: A worldwide, biogeographic analysis. Ecological Economics 105,154-165. DOI 10.1016/j.ecolecon.2014.05.008

de Oliveira JV, Lopes SF, Barboza RRD, Trovão DMMB, Ramos MB, Alves RRN. 2019. Wild vertebrates and their representation by urban/rural students in a region of northeast Brazil. Journal of Ethnobiology and Ethnomedicine 15,1-23. DOI 10.1186/s13002-0180283-y

de Villalobos AE, Peláez DV, Elia OR. 2005. Factors related to establishment of Prosopis caldenia Burk. seedlings in central rangelands of Argentina. Acta Oecologica 27,99106. DOI 10.1016/j.actao.2004.10.001 
550 de Villalobos AE, Peláez DV. 2015. Functional responses of woody Prosopis caldenia seedlings

551 to drought and livestock grazing in semiarid rangelands of Argentina. Arid Land

$552 \quad$ Research and Management 29,487-502. DOI 10.1080/15324982.2015.1030798

553 Dias DM, Massara RL, Bocchiglieri A. 2019. Use of habitats by donkeys and cattle within a

554 protected area of the Caatinga dry forest biome in northeastern Brazil. Perspectives in

555 Ecology and Conservation 17,64-70. DOI 10.1016/j.pecon.2019.04.005

556 dos Santos DM, Santos JMFF, Silva KA, Araújo VKR, Araújo EL. 2016. Composition, species

557 richness, and density of the germinable seed bank over 4 years in young and mature

558 forests in Brazilian semiarid regions. Journal of Arid Environments 129,93-101. DOI

$559 \quad$ 10.1016/j.jaridenv.2016.02.012

560 Dube S, Mlambo D, Sebata A. 2010. Response of Faidherbia albida (Del.) A. Chev., Acacia

561 nigrescens Oliver. and Acacia nilotica (L.) Willd ex Del. seedlings to simulated

562 cotyledon and shoot herbivory in a semi-arid savanna in Zimbabwe. African Journal of

563 Ecology 48,361-367. DOI 10.1111/j.1365-2028.2009.01119.x

564 El-Keblawy A, Abdelfatah MA. 2014. Impacts of native and invasive exotic Prosopis congeners

565 on soil properties and associated flora in the arid United Arab Emirates. Journal of Arid

566 Environments 100-101,1-8. DOI 10.1016/j.jaridenv.2013.10.001

567 Ferraz EMN, Rodal MJN, Sampaio EVSB. 2003. Physiognomy and structure of vegetation along

568

569 an altitudinal gradient in the semi-arid region of northeastern Brazil. Phytocoenologia

570 Francesca V, Osvaldo F, Stefano P, Paola RP. 2010. Soil moisture measurements: Comparison of instrumentation performances. Journal of Irrigation and Drainage Engineering 136,81-

572 89. DOI 10.1061/(ASCE)0733-9437(2010)136:2(81) 
573 Galindo ICL, Ribeiro MR, Santos MAV, Lima JFWF, Ferreira RFAL. 2008. Soils and

574

575

576

577

578

579

580

581

582

583

584

585

586

587

588

589

590

591

592

593

vegetation relations in areas under desertification in Jataúba county, Pernambuco State, Brazil. Revista Brasileira de Ciência do Solo 32,1283-1296. DOI 10.1590/S010006832008000300036

Garza JAV, Estrada AR, Cárdenas-Ávila ML, Limón SM, Álvarez MG, López VV. 2013. Morphometric characteristics, viability and germination of mesquite and sweet acacia seeds in northeastern Mexico. Phyton 82,169-174.

Gandhi DS, Pandian SS. 2014. Inventory of trees in tropical dry deciduous forests of Tiruvannamalai district, Tamil Nadu, India. Biodiversitas 15,169-179. DOI 10.13057/biodiv/d150208

Gil S, Al-Shankiti A. 2015. Priming of Prosopis cineraria (L.) Druce and Acacia tortilis (Forssk) seeds with fulvic acid extracted from compost to improve germination and seedling vigor. Global Journal of Environmental Science and Management 1,225-232. DOI 10.7508/gjesm.2015.03.005

Gilioli G, Schrader G, Baker RHA, Ceglarska E, Kertész VK, Lövei G, Navajas M, Rossi V, Tramontini S, van Lenteren JC. 2014. Environmental risk assessment for plant pests: A procedure to evaluate their impacts on ecosystem services. Science of the Total Environment 468-469,475-486. DOI 10.1016/j.scitotenv.2013.08.068

Goia I, Ciocanea C-M, Gavrilidis AA. 2014. Geographic origins of invasive alien species in "Iron Gates” Natural Park (Banat, Romania). Transylvanian Review of Systematical and Ecological Research 16,115-130. DOI 10.1515/trser-2015-0036

Peerj reviewing PDF | (2018:11:32872:2:2:NEW 3 Jun 2020) 
594 Gonçalves GS, Andrade LA, Gonçalves EP, Oliveira LSB, Dias JT. 2013. Physiological quality

595 of algaroba seeds recovered from faeces of mules. Semina-Ciências Agrárias 34,593-

596 602. DOI 10.5433/1679-0359.2013v34n2p593

597 Guo W-Y, van Kleunen M, Winter M, Weigelt P, Stein A, Pierce S, Pergl J, Moser D, Maurel N, 598 Lenzner B, Kreft H, Essl F, Dawson W, Pyšek P. 2018. The role of adaptive strategies in plant naturalization. Ecology Letters 21,1380-1389. DOI 10.1111/ele.13104

600

601

602

603

604

605

606

607

608

609

610

611

612

613

614

615

616 alien species introductions. Journal of Applied Ecology 52,1418-1424. DOI $10.1111 / 1365-2664.12470$

Hulme PE, Barrett SCH. 2013. Integrating trait- and niche-based approaches to assess contemporary evolution in alien plant species. Journal of Ecology 101,68-77. DOI $10.1111 / 1365-2745.12009$

Ilukor J, Rettberg S, Treydte A, Birner R. 2016. To eradicate or not to eradicate? Recommendations on Prosopis juliflora management in Afar, Ethiopia, from an interdisciplinary perspective. Pastoralism 6,1-8. DOI 10.1186/s13570-016-0061-1

Jauni M, Gripenberg S, Ramula S. 2015. Non-native plant species benefit from disturbance: A meta-analysis. Oikos 124,122-129. DOI 10.1111/oik.01416

Jiménez JJ, Lal R, Russo RO, Leblanc HA. 2008. The soil organic carbon in particle-size separates under different regrowth forest stands of north eastern Costa Rica. Ecological Engineering 34,300-310. DOI 10.1016/j.ecoleng.2008.07.001

Kalusová V, Chytrý M, Kartesz JT, Nishino M, Pyšek P. 2013. Where do they come from and where do they go? European natural habitats as donors of invasive alien plants globally. Diversity and Distributions 19,199-214. DOI 10.1111/ddi.12008 
617 Kebede AT, Coppock DL. 2015. Livestock-mediated dispersal of Prosopis juliflora imperils 618 grasslands and the endangered grevy's zebra in Northeastern Ethiopia. Rangeland 619 Ecology and Management 68,402-407. DOI 10.1016/j.rama.2015.07.002

620 Leal LC, Andersen AN, Leal IR. 2014. Anthropogenic disturbance reduces seed-dispersal 621 services for myrmecochorous plants in the Brazilian Caatinga. Oecologia 174,173-181. DOI 10.1007/s00442-013-2740-6

623

624

625

626

627

628

629

630

631

632

633

634

635

636

637

638

Leal IR, Silva JMC, Tabarelli M, Lacher Jr TE. 2005. Changing the course of biodiversity conservation in the Caatinga of northeastern Brazil. Conservation Biology 19,701-706. DOI 10.1111/j.1523-1739.2005.00703.x

Li Y, Liu X, Li X, Petitpierre B, Guisan A. 2014. Residence time, expansion toward the equator in the invaded range and native range size matter to climatic niche shifts in non-native species. Global Ecology and Biogeography 23,1094-1104. DOI 10.1111/geb.12191

Lopes HL, Cabral JJSP, Araújo Filho JC, Montenegro SMGL. 2013. Mapping alluvial areas in semi-arid region of Brazil through collateral data and satellite images. Revista Brasileira de Engenharia Agrícola e Ambiental 17,763-769. DOI 10.1590/S141543662013000700011

Lopes I, Montenegro AAA, Lima JLMP. 2019. Performance of conservation techniques for semiarid environments: Field observations with Caatinga, mulch, and cactus forage palma. Water 11,792. DOI 10.3390/w11040792

Lv X, Zhou G. 2018. Climatic suitability of the geographic distribution of Stipa breviflora in Chinese temperate grassland under climate change. Sustainability 10,3767. DOI $10.3390 / \mathrm{su} 10103767$ 
639 Maestre FT, Reynolds JF. 2006. Small-scale spatial heterogeneity in the vertical distribution of 640 soil nutrients has limited effects on the growth and development of Prosopis glandulosa seedlings. Plant Ecology 183,65-75. DOI 10.1007/s11258-005-9007-1

642

643

644

645

646

647

648

649

650

651

652

653

654

655

656

657

658

659

660

661

Majd R, Aghaie P, Monfared EK, Alebrahim MT. 2013. Evaluating of some treatments on breaking seed dormancy in mesquite. International Journal of Agronomy and Plant Production 4,1433-1439.

Malavasi M, Santoro R, Cutini M, Acosta ATR, Carranza ML. 2016. The impact of human pressure on landscape patterns and plant species richness in Mediterranean coastal dunes. Plant Biosystems - An International Journal Dealing with all Aspects of Plant Biology 150,73-82. DOI 10.1080/11263504.2014.913730

Malíková L, Mudrák O, Klimešová J. 2012. Adventitious sprouting enables the invasive annual herb Euphorbia geniculata to regenerate after severe injury. Ecological Research 27,841-847. DOI 10.1007/s11284-012-0960-6

Mamede MA, de Araújo FS. 2008. Effects of slash and burn practices on a soil seed bank of caatinga vegetation in Northeastern Brazil. Journal of Arid Environments 72,458-470. DOI 10.1016/j.jaridenv.2007.07.014

Marques FA, Ribeiro MR, Bittar SMB, Tavares Filho AN, Lima JFWF. 2007. Characterization and classification of neosols on the Fernando de Noronha Island, Pernambuco, Brazil. Revista Brasileira de Ciência do Solo 31,1553-1562. DOI 10.1590/S010006832007000600032

Martínez AJ, López-Portillo J. 2003. Allometry of Prosopis glandulosa var. torreyana along a topographic gradient in the Chihuahuan desert. Journal of Vegetation Science 4,111120. DOI 10.1111/j.1654-1103.2003.tb02133.x 
662 McGeoch MA, Genovesi P, Bellingham PJ, Costello MJ, McGrannachan C, Sheppard A. 2016.

663 Prioritizing species, pathways, and sites to achieve conservation targets for biological 664 invasion. Biological Invasions 18,299-314. DOI 10.1007/s10530-015-1013-1

665

666

667

668

669

670

671

672

673

674

675

676

677

678

679

680

681

682

683

Meloni DA. 2012. Physiological responses to calcium supplementation of NaCl-stressed vinal (Prosopis ruscifolia G.) seedlings. Revista de la Facultad de Ciencias Agrarias UNCuyo 44,79-88.

Miccolis A, Peneireiro FM, Vieira DLM, Marques HR, Hoffmann MRM. 2017. Restoration through agroforestry: Options for reconciling livelihoods with conservation in the Cerrado and Caatinga biomes in Brazil. Experimental Agriculture 1,1-18. DOI $10.1017 / \mathrm{S} 0014479717000138$

Miranda RQ, Correia RM, Almeida-Cortez JS, Pompelli MF. 2014. Germination of Prosopis juliflora (Sw.) D.C. seeds at different osmotic potentials and temperatures. Plant Species Biology 29,E9-E20. DOI 10.1111/1442-1984.12025

Miranda RQ, Oliveira MTP, Correia RM, Almeida-Cortez JS, Pompelli MF. 2011. Germination of Prosopis juliflora (Sw) DC seeds after scarification treatments. Plant Species Biology 26,186-192. DOI 10.1111/j.1442-1984.2011.00324.x

Moran EV, Reid A, Levine JM. 2017. Population genetics and adaptation to climate along elevation gradients in invasive Solidago canadensis. PLoS ONE 12,e0185539. DOI 10.1371/journal.pone.0185539

Morandini MN, Giamminola EM, Viana ML. 2013. Desiccation tolerance in seeds of Prosopis ferox and Pterogyne nitens (Fabaceae). Revista de Biología Tropical 61,335-342. DOI 10.15517/RBT.V61I1.11132 
684 Moravcová L, Pyšek P, Jarošík V, Pergl J. 2015. Getting the right traits: Reproductive and 685 dispersal characteristics predict the invasiveness of herbaceous plant species. PLoS

686 ONE 10,e0123634. DOI 10.1371/journal.pone.0123634

687

688

689

690

691

692

693

694

695

696

697

698

699

700

701

702

703

704

705

706

Moro MF, Lughadha EN, Araújo FS, Martins FR. 2016. A phytogeographical metaanalysis of the Semiarid Caatinga Domain in Brazil. Botanical Review 82,91-148. DOI $10.1007 / \mathrm{s} 12229-016-9164-\mathrm{z}$

Mukherjee AM, Velankar AD, Kumara HN. 2017. Invasive Prosopis juliflora replacing the native floral community over three decades: A case study of a world heritage site, Keoladeo National Park, India. Biodiversity and Conservation 26,2839-2856. DOI 10.1007/s10531-017-1392-y

Mullah CJA, Klanderud K, Totland Ø, Odee D. 2014. Community invasibility and invasion by non-native Fraxinus pennsylvanica trees in a degraded tropical forest. Biological Invasions 16,2747-2755. DOI 10.1007/s10530-014-0701-6

Nascimento CED, Tabarelli M, Silva CA, Leal IR, Souza Tavares W, Serrão JE, Zanuncio JC. 2014. The introduced tree Prosopis juliflora is a serious threat to native species of the Brazilian Caatinga vegetation. Science of the Total Environment 481,108-113. DOI 10.1016/j.scitotenv.2014.02.019

Nasr SMH, Parsakhoo A, Naghavi H, Koohi SKS. 2012. Effect of salt stress on germination and seedling growth of Prosopis juliflora (Sw.). New Forests 43,45-55. DOI $10.1007 / \mathrm{s} 11056-011-9265-9$

Naudiyal N, Joachim S, Stefanie G. 2017. What influences the plant community composition on Delhi ridge? The role played by Prosopis juliflora and anthropogenic disturbances. Tropical Ecology 58,33-43. 
707 Novoa A, Le Roux JJ, Robertson MP, Wilson JRU, Richardson DM. 2015. Introduced and

708 invasive cactus species: A global review. AoB Plants 7,plu078. DOI

709 10.1093/aobpla/plu078

710

711

712

713

714

715

716

717

718

719

720

721

722

723

724

725

726

727

728

Oliveira LSB, Andrade LA, Fabricante JR, Gonçalves GS. 2012. Structure of a Prosopis juliflora (Sw.) DC. population established in a temporary riverbed in the Microregion of Cariri in the State of Paraiba. Semina: Ciências Agrárias 33,1769-1778. DOI 10.5433/16790359.2012v33n5p 1769

Oliveira MT, Souza GM, Pereira S, Oliveira DAS, Figueiredo-Lima KV, Arruda E, Santos MG. 2017. Seasonal variability in physiological and anatomical traits contributes to invasion success of Prosopis juliflora in tropical dry forest. Tree Physiology 37,326-337. DOI 10.1093/treephys/tpw123

Oliveira OF, Santos MVF, Cunha MV, Dubeux Júnior JCB, Muir JP, Mello ACL, Lira MA, Barros GFNP. 2016. Botanical composition of Caatinga rangeland and diets selected by grazing sheep. Tropical Grasslands 4,71-81. DOI 10.17138/TGFT(4)71-81

Pasha SV, Satish KC, Reddy CS, Jha CS. 2015. Massive invasion of mesquite (Prosopis juliflora) in Wild Ass Wildlife Sanctuary, India. National Academy Science Letters 38,271-273. DOI 10.1007/s40009-014-0321-9

Patil AV, Karadge BA. 2012. Effect of $\mathrm{NaCl}$ salinity on the growth and mineral nutrition of one month old Prosopis juliflora (Sw.) DC seedlings. Pharmacognosy Journal 4,63-66. DOI $10.5530 /$ pj.2012.31.12

Pegado CMA, Andrade LA, Félix LP, Pereira IM. 2006. Effects of the biological invasion of algaroba - Prosopis juliflora (Sw.) DC. on composition and structure of the shrubtree 

Brasilica 20,887-898. DOI 10.1590/S0102-33062006000400013

731

732

733

734

735

736

737

738

739

740

741

742

743

744

745

746

747

748

749

750

751

FL, Cortés JG, Guzmán JMS. 2015. Seed germination and risks of using the invasive plant Eichhornia crassipes (Mart.) Solms-Laub. (water hyacinth) for composting, ovine feeding and biogas production. Acta Botanica Gallica 162,203-214. DOI $10.1080 / 12538078.2015 .1056227$

Pérez-Marin AM, Rogé P, Altieri MA, Forer LFU, Silveira L, Oliveira VM, Domingues-Leiva BE. 2017. Agroecological and social transformations for coexistence with semi-aridity in Brazil. Sustainability 9,990. DOI 10.3390/su9060990

Perkins LB, Nowak RS. 2013. Invasion syndromes: Hypotheses on relationships among invasive species attributes and characteristics of invaded sites. Journal of Arid Land 5,275-283. DOI 10.1007/s40333-013-0161-3

Rathore VS, Singh JP, Bhardwaj S, Nathawat NS, Kumar M, Roy MM. 2015. Potential of native shrubs Haloxylon salicornicum and Calligonum Polygonoides for restoration of degraded lands in Arid Western Rajasthan, India. Environmental Management 55,205216. DOI 10.1007/s00267-014-0372-1

Rai PK. 2015. What makes the plant invasion possible? Paradigm of invasion mechanisms, theories and attributes. Environmental Skeptics and Critics 4,36-66.

Ramos CMC, Silva AF, Sartori AAC, Zimback CRL, Bassoi LH. 2011. Modeling the hourly variation of air temperature at Petrolina and Botucatu, Brazil. Revista Brasileira de Engenharia Agrícola e Ambiental 15,959-965. DOI 10.1590/S141543662011000900012 
752 Razanamandranto S, Tigabu M, Neya S, Odén PC. 2004. Effects of gut treatment on recovery

753

754

755

756

757

758

759

760

761

762

763

764

765

766

767

768

769

770

771

772

773

774

and germinability of bovine and ovine ingested seeds of four woody species from the Sudanian savanna in West Africa. Flora - Morphology, Distribution, Functional Ecology of Plants 199,389-397. DOI 10.1078/0367-2530-00167

Ribeiro EMS, Arroyo-Rodríguez V, Santos BA, Tabarelli M, Leal IR. 2015. Chronic anthropogenic disturbance drives the biological impoverishment of the Brazilian Caatinga vegetation. Journal of Applied Ecology 52,611-620. DOI 10.1111/13652664.12420

Risio L, Calama R, Bogino SM, Bravo F. 2016. Inter-annual variability in Prosopis caldenia pod production in the Argentinean semiarid pampas: A modelling approach. Journal of Arid Environments 131,59-66. DOI 10.1016/j.jaridenv.2016.03.007

Rito KF, Arroyo-Rodríguez V, Queiroz RT, Leal IR, Tabarelli M. 2017. Precipitation mediates the effect of human disturbance on the Brazilian Caatinga vegetation. Journal of Ecology 105,828-838. DOI 10.1111/1365-2745.12712

Rivaes R, Rodríguez-González PM, Albuquerque A, Pinheiro AN, Egger G, Ferreira MT. 2013. Riparian vegetation responses to altered flow regimes driven by climate change in Mediterranean rivers. Ecohydrology 6,413-424. DOI 10.1002/eco.1287

Rivaes RP, Rodríguez-González PM, Ferreira MT, Pinheiro AN, Politti E, Egger G, García-Arias A, Francés F. 2014. Modeling the evolution of riparian woodlands facing climate change in three European rivers with contrasting flow regimes. PLoS ONE 9,e110200. DOI 10.1371/journal.pone.0110200

Roy HE, Peyton J, Aldridge DC, Bantock T, Blackburn TM, Britton R, Clark P, Cook E, Dehnen-Schmutz K, Dines T, Dobson M, Edwards F, Harrower C, Harvey MC, 
775

776

777

778

779

780

781

782

783

784

785

786

787

788

789

790

791

792

793

794

795

796

797

Minchin D, Noble DG, Parrott D, Pocock MJO, Preston CD, Roy S, Salisbury A, Schönrogge K, Sewell J, Shaw RH, Stebbing P, Stewart AJA, Walker KJ. 2014.

Horizon scanning for invasive alien species with the potential to threaten biodiversity in Great Britain. Global Change Biology 20,3859-3871. DOI 10.1111/gcb.12603

Sampaio EVSB, Costa TL. 2011. Stocks and fluxes of carbon in semiarid northeast Brazil: Preliminary estimates. Revista Brasileira de Geografia Física 6,1275-1291. DOI 10.26848/rbgf.v4i6.232783

Santos JPO, Silva Júnior JM, Silva Filho JA, Silva JLC, Ribeiro JKN, Oliveira FIF. 2017. Environmental degradation and risk of desertification in Alto Sertão Region, Alagoas State, Brazil. Revista Geama 3,191-195.

Santos JPS, Diodato MA. 2015. Carob tree (Prosopis juliflora) in north Rio Grande caatinga: Analysis of the municipality of Fernando Pedroza. Nature and Conservation 8,13-21. DOI 10.6008/SPC2318-2881.2015.001.0002

Schulz C, Koch R, Cierjacks A, Kleinschmit B. 2017. Land change and loss of landscape diversity at the Caatinga phytogeographical domain - Analysis of pattern-process relationships with MODIS land cover products (2001-2012). Journal of Arid Environments 136,54-74. DOI 10.1016/j.jaridenv.2016.10.004

Sfair JC, Bello F, França TQ, Baldauf C, Tabarelli M. 2018. Chronic human disturbance affects plant trait distribution in a seasonally dry tropical forest. Environmental Research Letters 13,025005. DOI 10.1088/1748-9326/aa9f5e

Shackleton RT, Le Maitre DC, Richardson DM. 2015. Prosopis invasions in South Africa: Population structures and impacts on native tree population stability. Journal of Arid Environments 114,70-78. DOI 10.1016/j.jaridenv.2014.11.006 
798 Shiferaw H, Teketay D, Nemomissa S, Assefa F. 2004. Some biological characteristics that 799 foster the invasion of Prosopis juliflora (Sw.) DC. at Middle Awash Rift Valley Area, 800 north-eastern Ethiopia. Journal of Arid Environments 58,135-154. DOI $801 \quad$ 10.1016/j.jaridenv.2003.08.011

802 Silva AC, Souza AF. 2018. Aridity drives plant biogeographical sub regions in the Caatinga, the

803 804 805 806 807 808 809 810

811 largest tropical dry forest and woodland block in South America. PLoS ONE 13,e0196130. DOI 10.1371/journal.pone.0196130

Silva JMC, Leal IR, Tabarelli M. 2017. Caatinga: The largest dry forest region in South America. Cahm: Springer International Publishing. 482 p. DOI 10.1007/978-3-31968339-3

Silva LCR, Sternberg L, Haridasan M, Hoffmann WA, Miralles-Wilhelm F, Franco AC. 2008. Expansion of gallery forests into central Brazilian savannas. Global Change Biology 14,2108-2118. DOI 10.1111/j.1365-2486.2008.01637.x

Silva FKG, Lopes SF, Lopez LCS, Melo JIM, Trovão DMBM. 2014. Patterns of species richness and conservation in the Caatinga along elevational gradients in a semiarid ecosystem. Journal of Arid Environments 110,47-52. DOI 10.1016/j.jaridenv.2014.05.011

Simberloff D, Martin JL, Genovesi P, Maris V, Wardle DA, Aronson J, Courchamp F, Galil B, García-Berthou E, Pascal M, Pyšek P, Sousa R, Tabacchi E, Vilà M. 2013. Impacts of biological invasions: What's what and the way forward. Trends in Ecology and Evolution 28,58-66. DOI 10.1016/j.tree.2012.07.013

Song G, Li X, Hui R. 2017. Effect of biological soil crusts on seed germination and growth of an exotic and two native plant species in an arid ecosystem. PLoS ONE 12,e0185839. DOI 10.1371/journal.pone.0185839 
821 Svenning J-C, Gravel D, Holt RD, Schurr FM, Thuiller W, Münkemüller T, Schiffers KH,

822

823

824

825

826

827

828

829

830

831

832

833

834

835

836

837

838

839

840

841

Dullinger S, Edwards Jr TC, Hickler T, Higgins SI, Nabel JEMS, Pagel J, Normand S. 2014. The influence of interspecific interactions on species range expansion rates. Ecography 37,1198-1209. DOI 10.1111/j.1600-0587.2013.00574.x

Terra MCN, Santos RM, Prado Júnior JA, Mello JM, Scolforo JRS, Fontes MAL, Schiavini I, Reis AA, Bueno IT, Magnago LFS, ter Steege H. 2018. Water availability drives gradients of tree diversity, structure and functional traits in the Atlantic-CerradoCaatinga transition, Brazil. Plant Ecology 11,803-814. DOI 10.1093/jpe/rty017

Tukey JW. 1949. Comparing individual means in the Analysis of Variance. Biometrics 5,99114. DOI $10.2307 / 3001913$

Vavra M, Parks CG, Wisdom MJ. 2007. Biodiversity, exotic plant species, and herbivory: The good, the bad, and the ungulate. Forest Ecology and Management 246,66-72. DOI 10.1016/j.foreco.2007.03.051

van Kleunen M, Dawson W, Maurel WD. 2015. Characteristics of successful alien plants. Molecular Ecology 24,1954-1968. DOI 10.1111/mec.13013

van Wilgen BW, Richardson DM. 2014. Challenges and trade-offs in the management of invasive alien trees. Biological Invasions 16,721-734. DOI 10.1007/s10530-013-0615-8

Velarde M, Felker P, Gardiner D. 2005. Influence of elemental sulfur, micronutrients, phosphorus, calcium, magnesium and potassium on growth of Prosopis alba on high $\mathrm{pH}$ soils in Argentina. Journal of Arid Environments 62,525-539. DOI

10.1016/j.jaridenv.2005.01.022

Peer) reviewing PDF | (2018:11:32872:2:2:NEW 3 Jun 2020) 
842 Walkie TT, Hoag D, Evangelista PH, Luizza M, Laituri M. 2016. Is control through utilization a

843

844

845

846

847

848

849

850

851

852

853

854

855

856 cost effective Prosopis juliflora management strategy? Journal of Environmental Management 168,74-86. DOI 10.1016/j.jenvman.2015.11.054

Wallis K. 1952. Use of ranks in one-criterion variance analysis. Journal of the American Statistical Association 47,583-621. DOI 10.1080/01621459.1952.10483441

Westphal C, Gachón P, Bravo J, Navarrete C, Salas C, Ibáñez C. 2015. The potential of algarrobo (Prosopis chilensis (Mol.) Stuntz) for regeneration of desertified soils: Assessing seed germination under saline conditions. Environmental Management 56,209-220. DOI 10.1007/s00267-015-0490-4

Yoda K, Tsuji W, Inoue T, Saito T, Elbasit MAMA, Eldoma AM. 2015. Evaluation of the effect of a rain pulse on the initial growth of Prosopis seedlings. Arid Land Research and Management 29,210-221. DOI 10.1080/15324982.2014.943376

Zapala MN, Ellzey JT, Bader J, Peralta-Videa JR, Gardea-Torresdey J. 2014. Effects of copper sulfate on seedlings of Prosopis pubescens (screwbean mesquite). International Journal of Phytoremediation 16,1031-1041. DOI 10.1080/15226514.2013.810582 
Figure 1

Field capacity (A) and soil moisture (B) in flooding plain, alluvial terrace and plateau habitats, at $0-20 \mathrm{~cm}$ depth in a Caatinga dry forest, Brazil.

Tukey's Honest Significant (field capacity) and Kruskal-Wallis (soil moisture) tests. Columns followed by the same letter are similar $(p<0.05)$. Error bars indicate standard deviation.

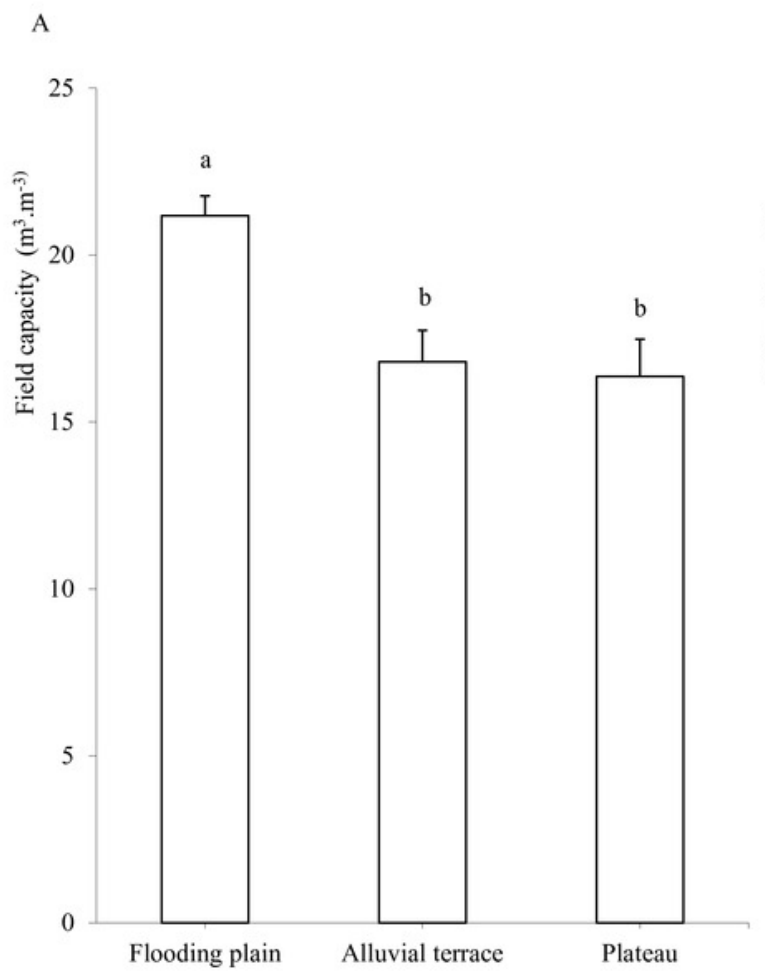

Habitats

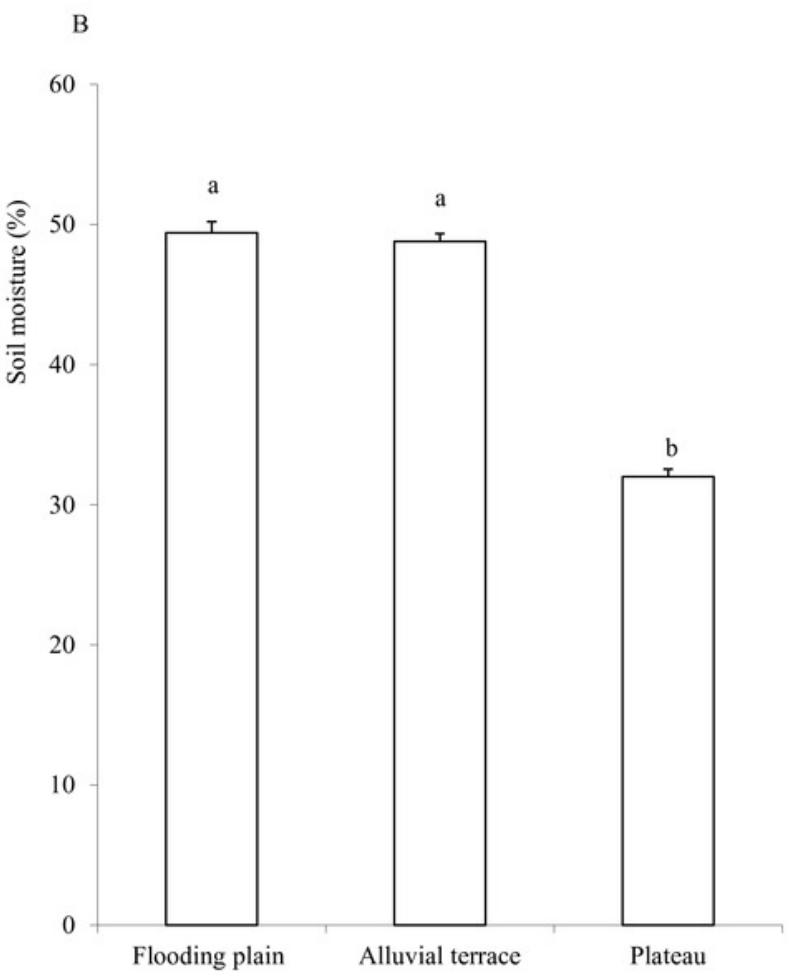

Habitats 


\section{Figure 2}

Tukey's Honest Significant (sand and silt) and Kruskal-Wallis (clay, OM, P, K, Ca, Mg, Al and CEC) tests. Columns followed by same letter are similar $(p=0.05)$. Error bars indicate standard deviation.

Particle size (A) and organic matter (OM) $\left(\mathrm{g} \cdot \mathrm{Kg}^{-1}\right)$, phosphorus $(\mathrm{P})\left(\mathrm{mg} \cdot \mathrm{dm}^{-3}\right)$, potassium (K) $\left(\mathrm{cmolc} . \mathrm{dm}^{-3}\right)$, calcium (Ca) $\left(\mathrm{cmolc} . \mathrm{dm}^{-3}\right)$, magnesium $(\mathrm{Mg})\left(\mathrm{cmolc} \cdot \mathrm{dm}^{-3}\right)$, aluminum (Al) $\left(\mathrm{cmolc} \cdot \mathrm{dm}^{-3}\right)$ and cation exchange capacity (CEC) $\left(\mathrm{cmolc}^{\mathrm{dm}}{ }^{-3}\right)(\mathrm{B})$, at $0-20 \mathrm{~cm}$ depth in a Caatinga dry forest, Brazil.

A

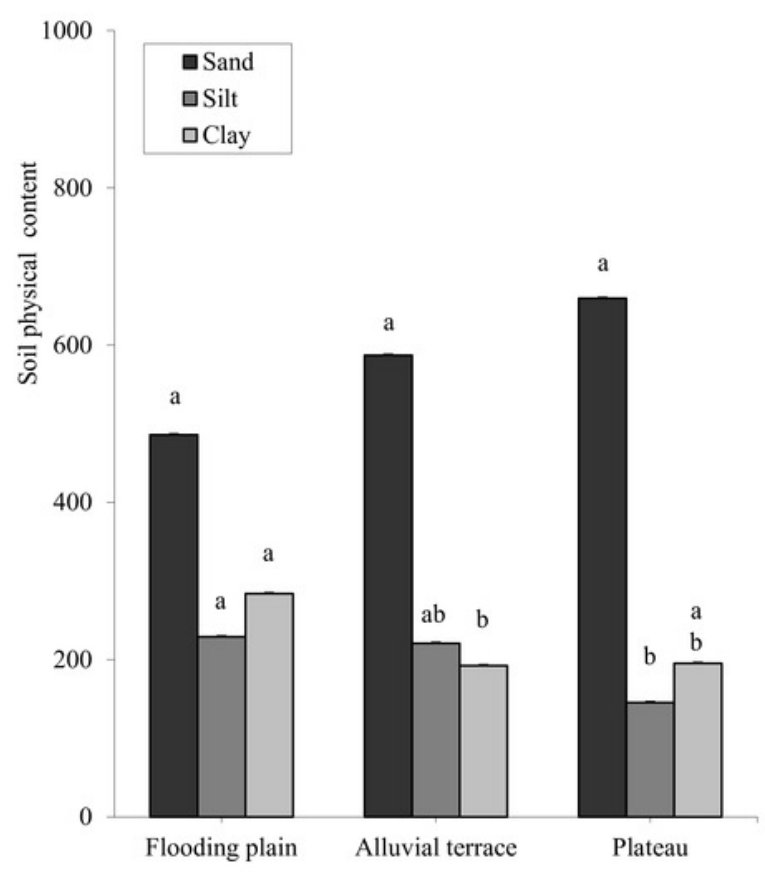

Habitats

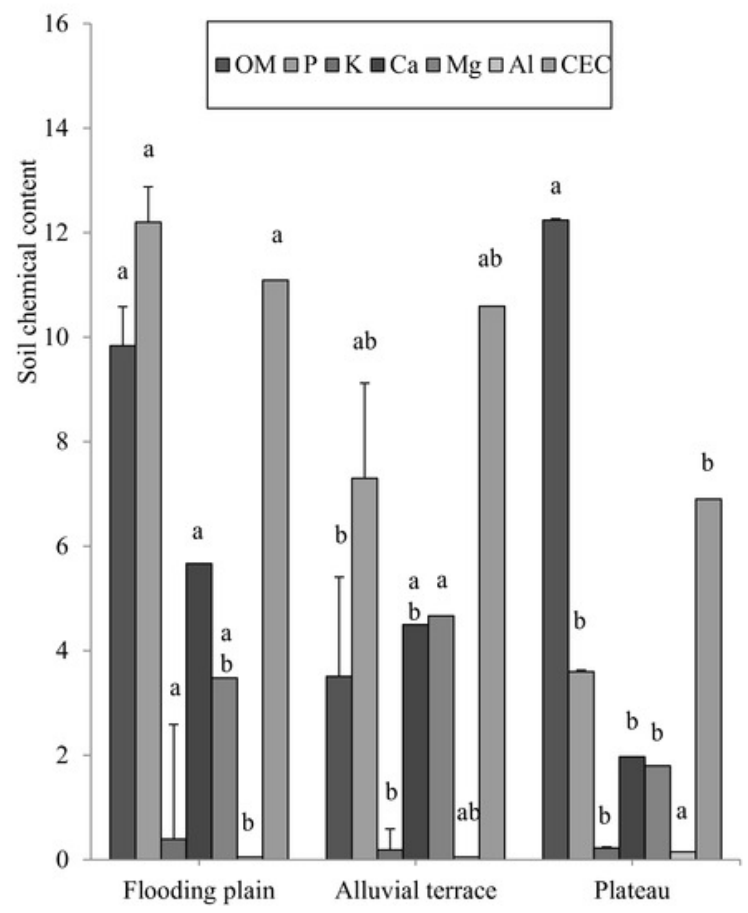

Habitats 
Figure 3

Survival $\left(I_{x}\right)$ and life expectancy $\left(e_{x}\right)$ of Prosopis juliflora sown on the soil surface $(A)$, buried

(B) or mixed with cattle (C) or mule (D) manure in the flooding plain habitat up to 345 days in a Caatinga dry forest, Brazil.
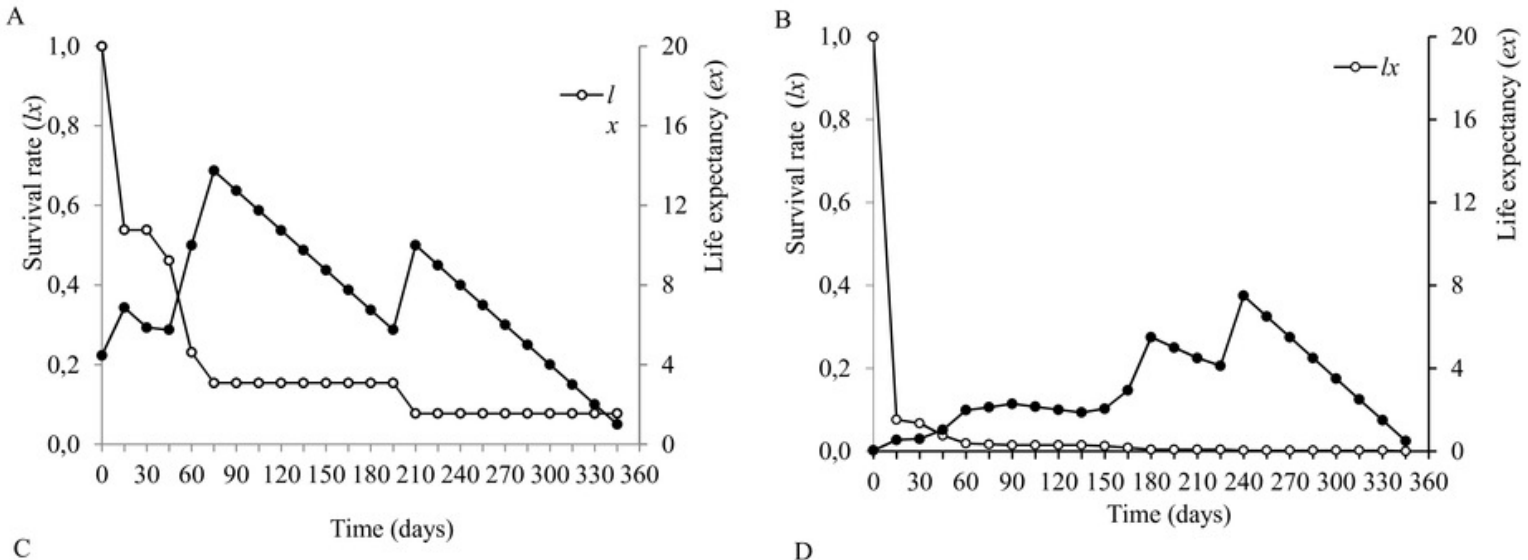

$$
\mathrm{C}
$$

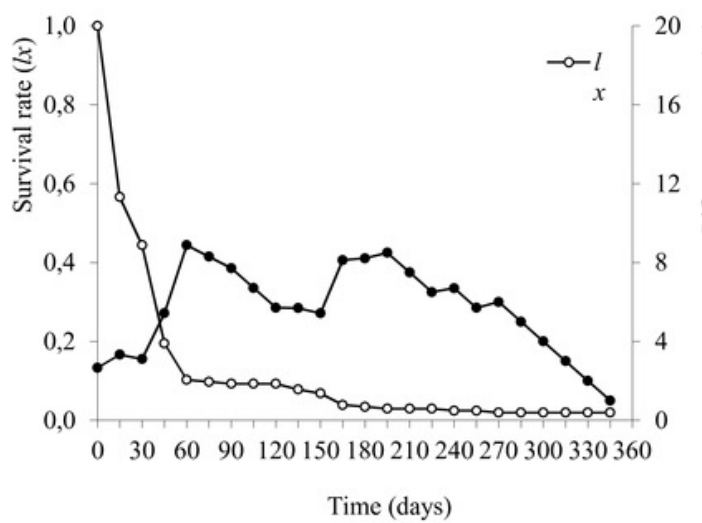

D

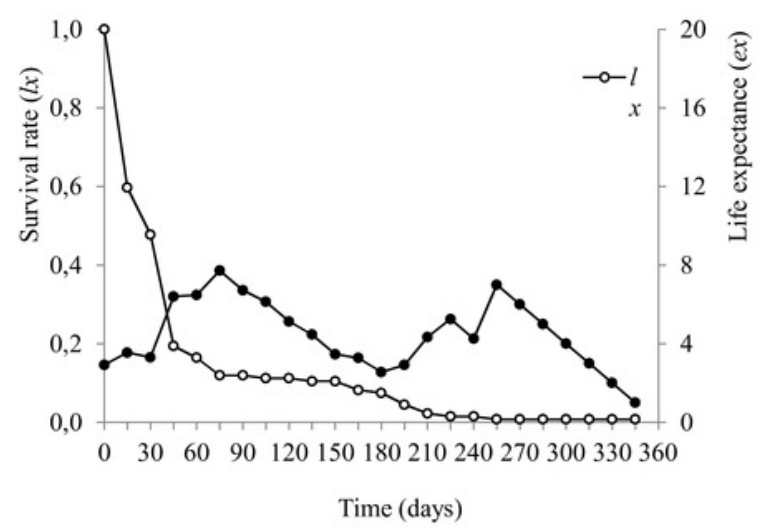


Figure 4

Survival $\left(I_{x}\right)$ and life expectancy $\left(e_{x}\right)$ of Prosopis juliflora sown on the soil surface $(A)$, buried (B) or mixed with cattle (C) or mule (D) manure in the alluvial terrace habitat up to 165 days in a Caatinga dry forest, Brazil.

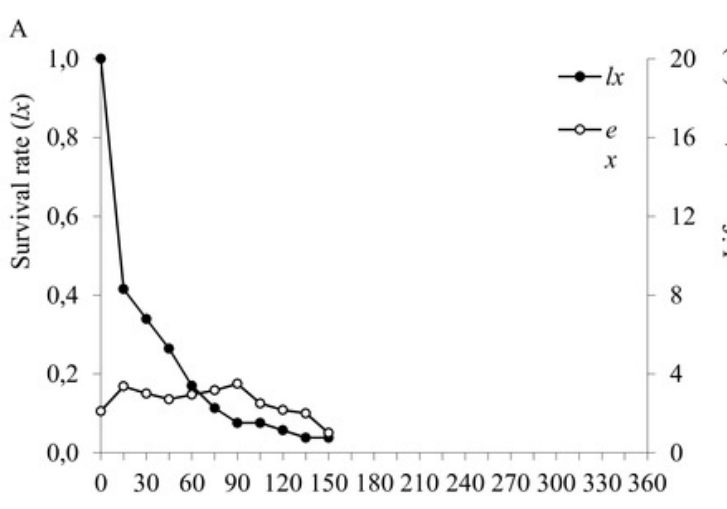

Time (days)

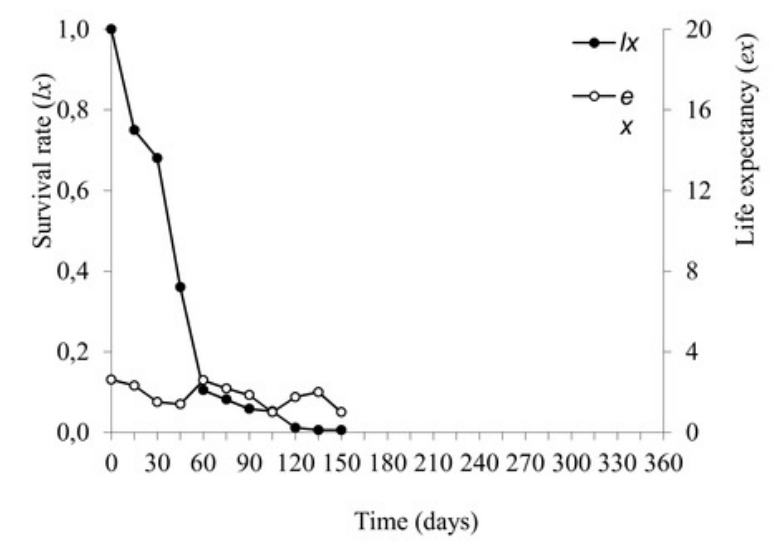

B

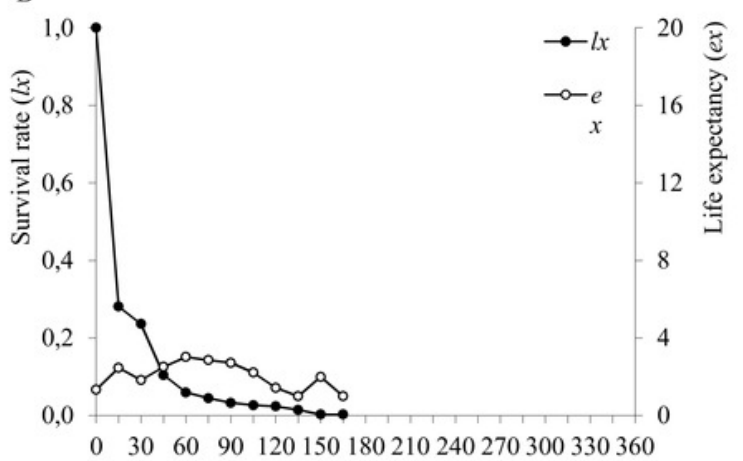

Time (days) . 
Figure 5

Survival $\left(I_{x}\right)$ and life expectancy $\left(e_{x}\right)$ of Prosopis juliflora sown on the soil surface $(A)$, buried

(B) or mixed with cattle (C) or mule (D) manure in the plateau habitat up to 165 days in a Caatinga dry forest, Brazil.
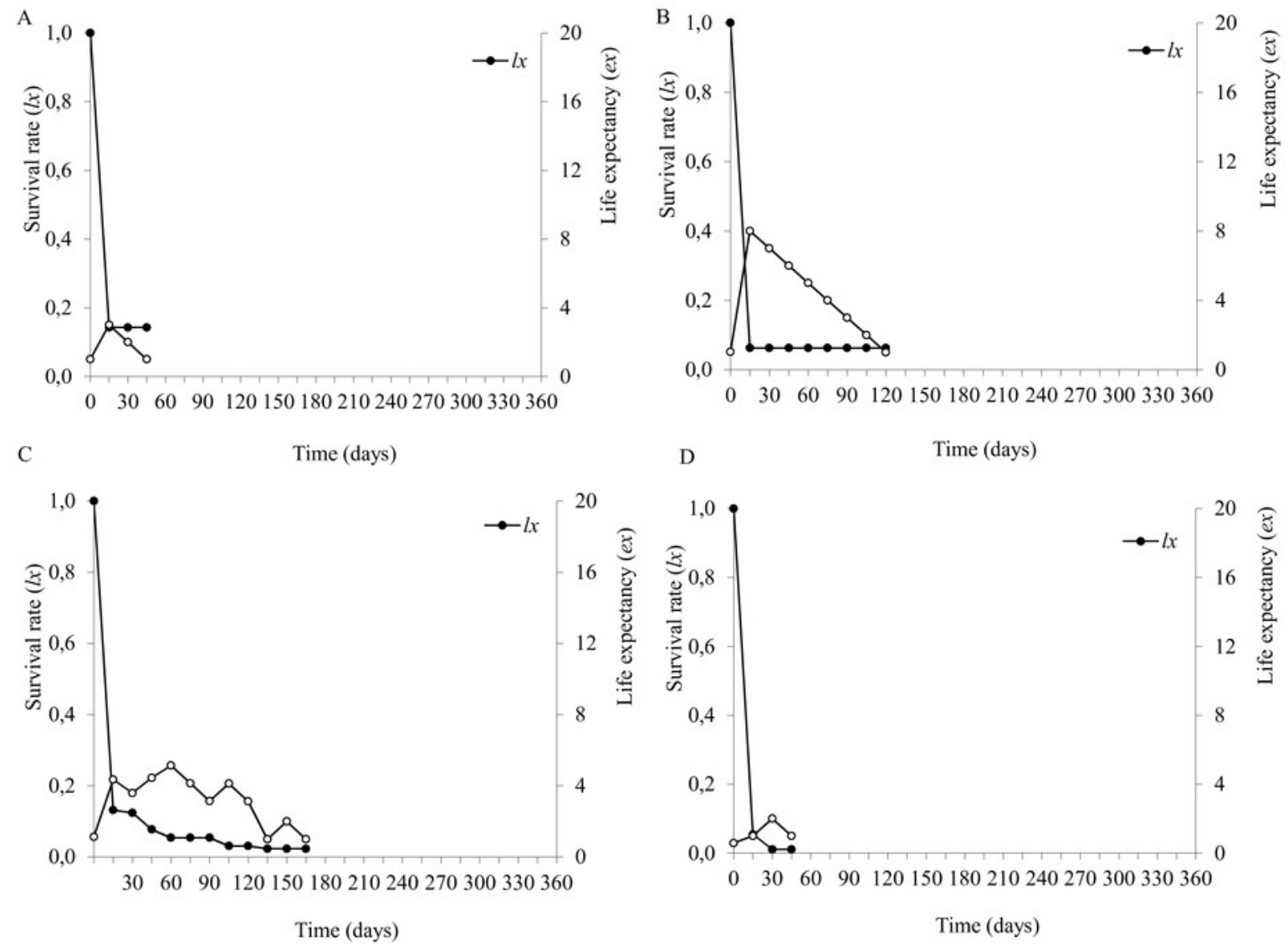

D

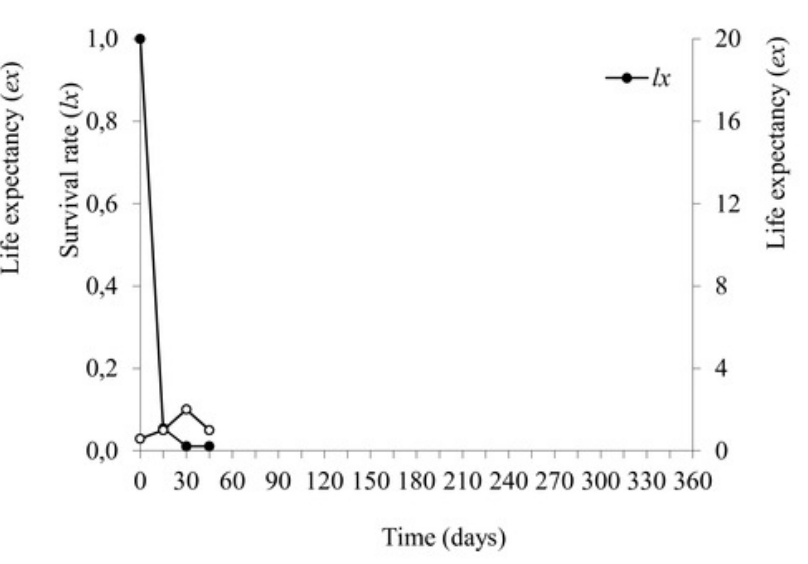




\section{Table $\mathbf{1}$ (on next page)}

Germination (\%) (mean \pm SD) of Prosopis juliflora seeds across three habitats and four seed dispersal treatments in the Caatinga dry forest, Brazil (a total of 12,000 seeds, 10 replicates).

${ }^{1}$ Means across seed dispersal modes sharing lower-case letters did not differ (Tukey test, $P<$ 0.001). ${ }^{2}$ Means across habitats sharing higher-case letters did not differ (Tukey test, $P<$ 0.001). 


\begin{tabular}{lccc}
\hline Seed dispersal modes & \multicolumn{3}{c}{ Habitats } \\
\cline { 2 - 4 } & Flooding plain & Terrace & Plateau \\
\hline Seeds on soil surface & $1.3 \pm 2.7 \mathrm{c}^{1} \mathrm{~A}^{2}$ & $5.3 \pm 6.7 \mathrm{cA}$ & $0.7 \pm 1.6 \mathrm{bA}$ \\
Buried seeds & $47.4 \pm 25.3 \mathrm{aA}$ & $33.4 \pm 25.8 \mathrm{aA}$ & $1.6 \pm 4.3 \mathrm{bB}$ \\
Cattle-dispersed seeds & $20.5 \pm 5.6 \mathrm{bA}$ & $17.2 \pm 4.7 \mathrm{aA}$ & $12.9 \pm 3.1 \mathrm{aA}$ \\
Mule-dispersed seeds & $13.4 \pm 6.1 \mathrm{bcA}$ & $11.7 \pm 6.3 \mathrm{bA}$ & $9.2 \pm 3.7 \mathrm{aA}$ \\
\hline
\end{tabular}




\section{Table 2 (on next page)}

Statistical scores of a two-way ANOVA for seed germination in a Caatinga dry forest, Brazil. The number of germinated seeds was square-rooted transformed prior analysis. 


\begin{tabular}{llllll}
\hline Source of variation & $F$ & d.f. & SQ & QM & $P$ \\
\hline Seed dispersal mode & 25.5 & 3 & 164.71 & 54.9 & $<0.01$ \\
Habitat & 38.7 & 2 & 74.87 & 37.43 & $<0.01$ \\
Interaction & 12.1 & 6 & 102.72 & 17.12 & $<0.01$ \\
Error & - & 108 & 152.95 & 1.4 & - \\
\end{tabular}

